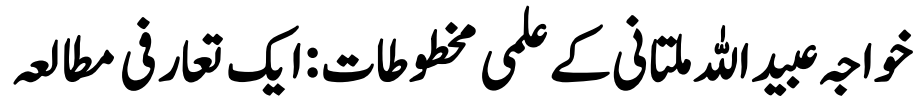

\section{An Introductory Study of Manuscripts of Khwāja Obāidullah Multani}

*Hafiz Muhammad Hassan Mahmood

**Mazhar Hussain Bhadro

\section{Abstract}

Research in manuscripts is an essential and inevitable part of Islamic Sciences. Scholastic and historical essence of beliefs and commandments including social values lie in manuscripts. Manuscripts not only introduce new generation with predecessors but also provide principles leading towards future destination. Manuscripts enable one to recognize human being and it becomes possible to look through embrasure of the past. These reflect one's familiarity with evolutionary phases as well as dogmatic thoughts. When printing press was not invented and access of scholastic community to this printing press was beyond their limits, people formulated manuscripts to save their memories. Here is presented a brief introduction of repository of manuscripts on Islamic jurisprudence compiled by a well known personality of 13th century hijrī, Mufti Khwāja Ubāidullah Multani.

This Paper provides a brief introduction o the fourteen manuscripts of Khwāja Ubāidullah Multani on Islamic jurisprudence .Methodology of these manuscripts is analyzed and explained by quotations. The writer had surely considered the time and space factor in analyzing jurisprudential issues. In all his Persian, Arabic and Urdu manuscripts Islamic laws and their details has been discussed in ordinary terms for the better understanding of general public.

Keywords: Islamic Jurisprudence, Introductory Study, Khwāja Obāidullah Multani, Manuscripts.

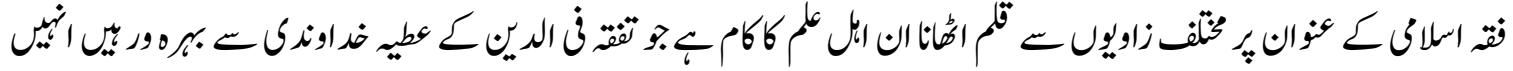

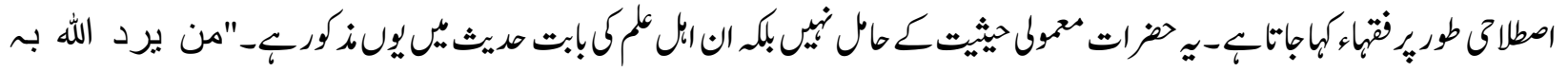

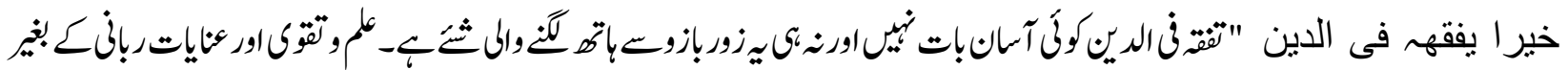

\footnotetext{
* Research Scholar \& PhD Scholar, Dept. of Islamic Studies B. Z. University. Multan,irhasan.mahmood@gmail.com.

** Ph.D. Scholar, Dept. of Arabic\&Islamic Studies G. College University Lahore.mazharhussainbhadroo@gmail.com
} 


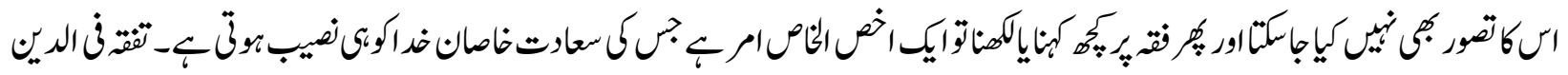

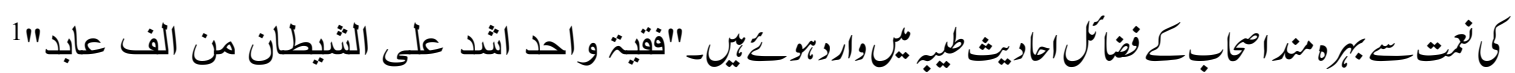

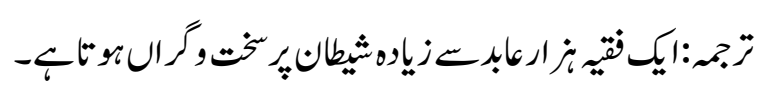

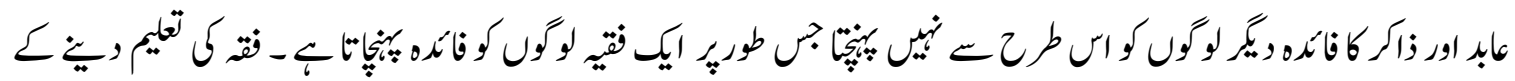

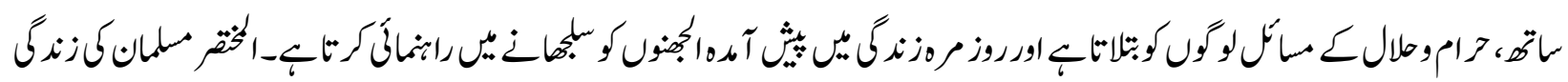

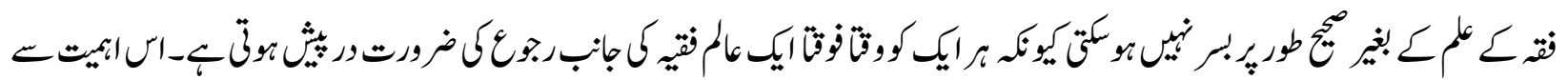

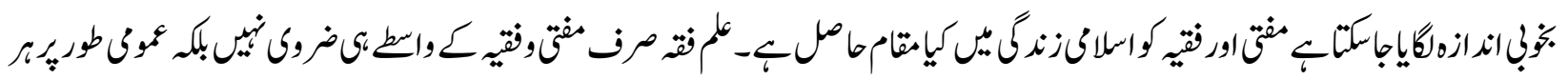

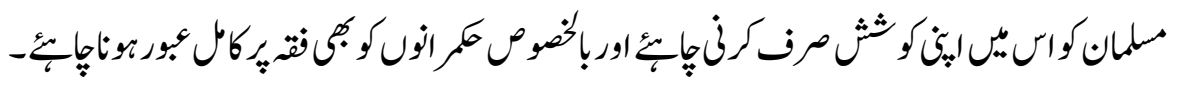

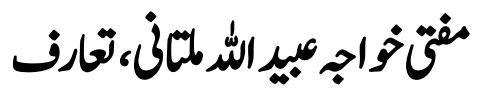

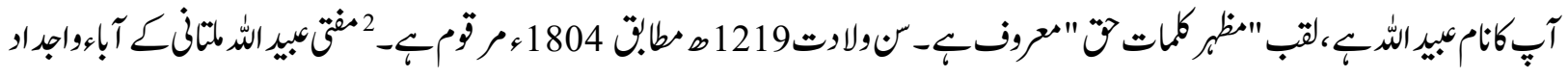

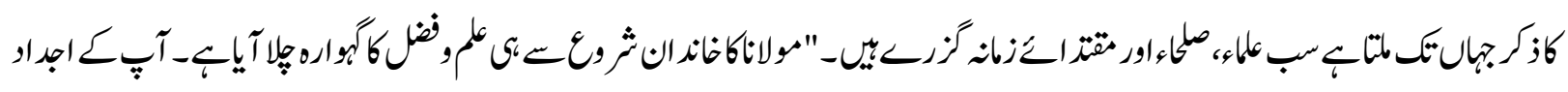

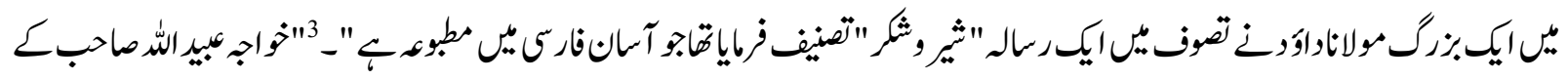

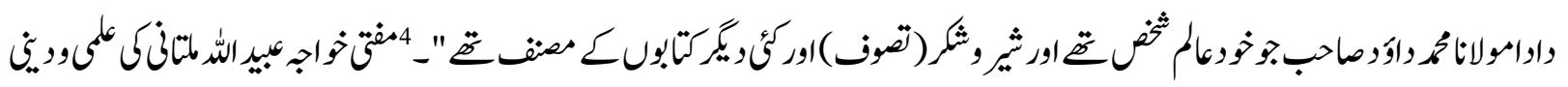

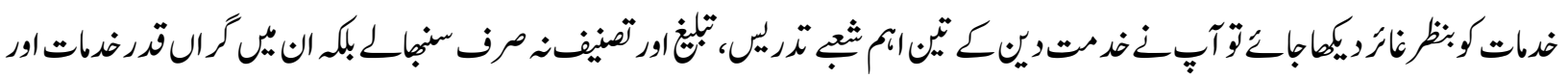

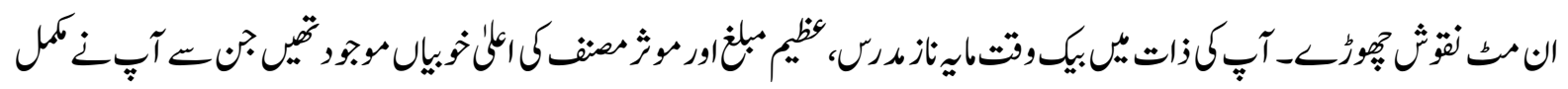

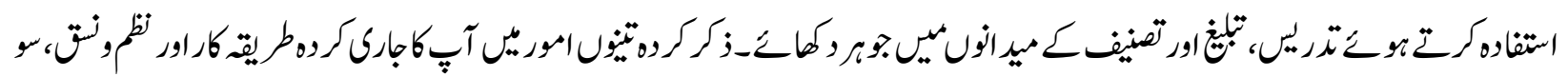

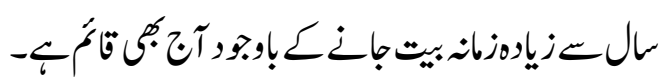

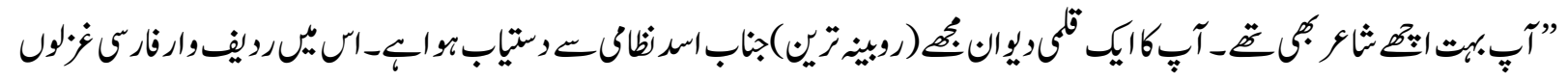

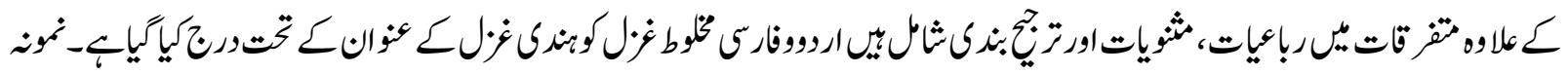
حببزيل؛

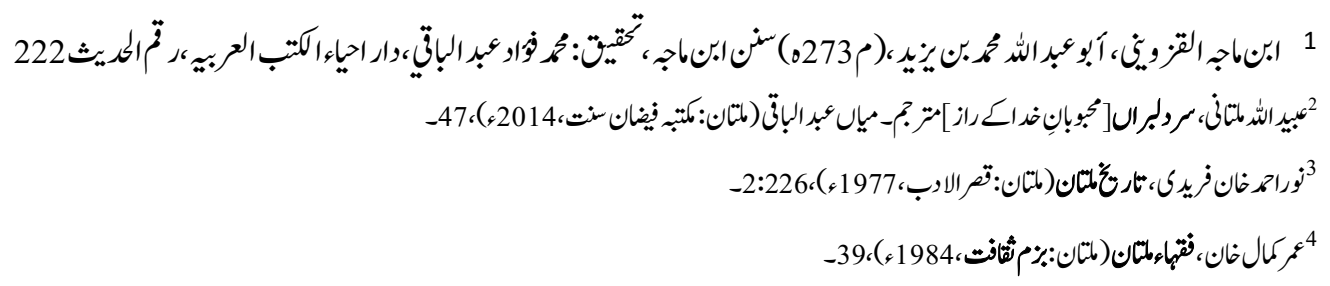




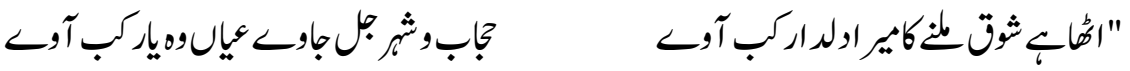

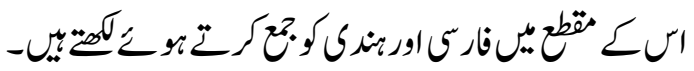

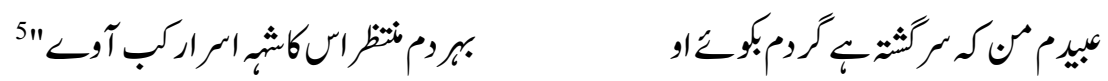

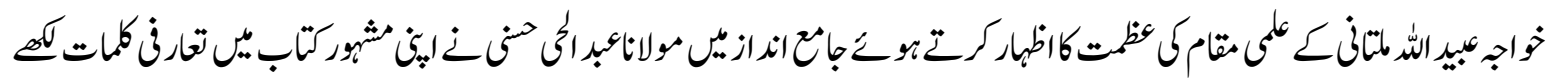

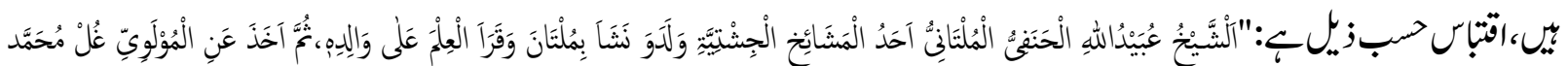

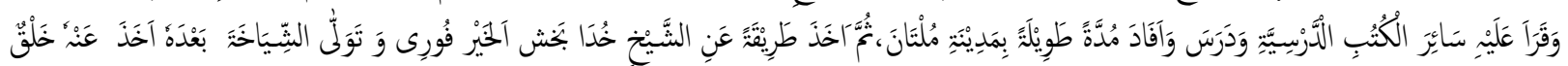

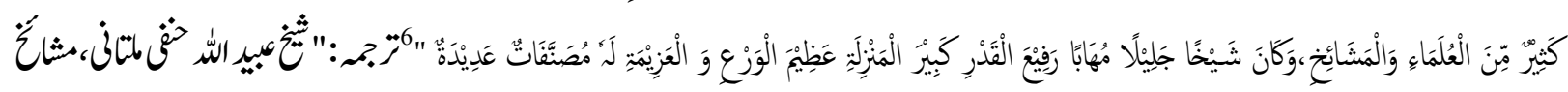

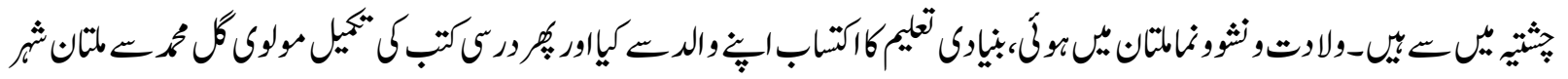

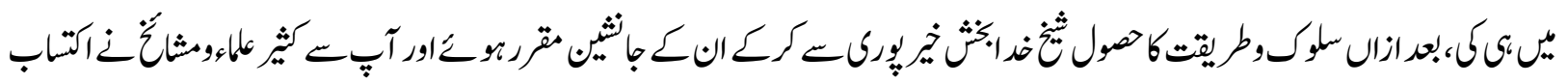

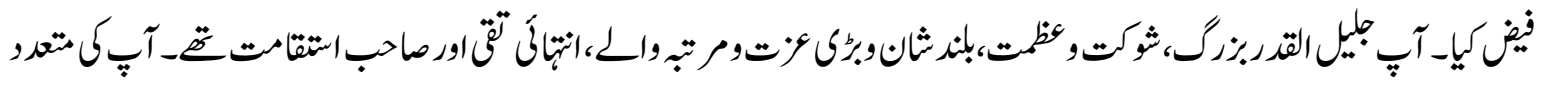
تصنيفاتبيل-"

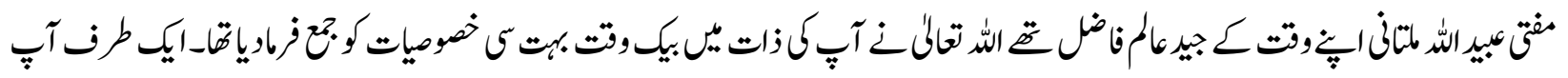

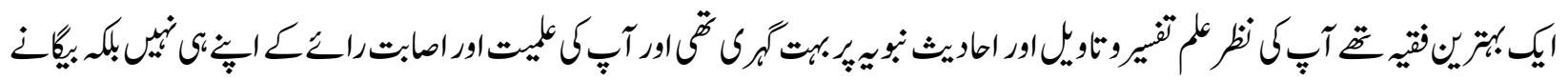

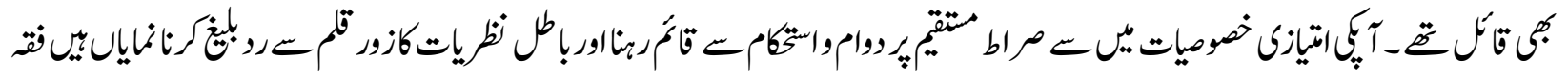

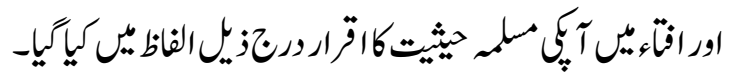

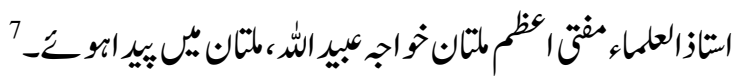

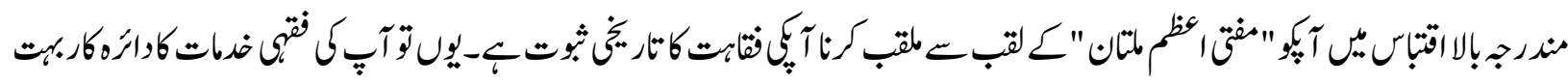

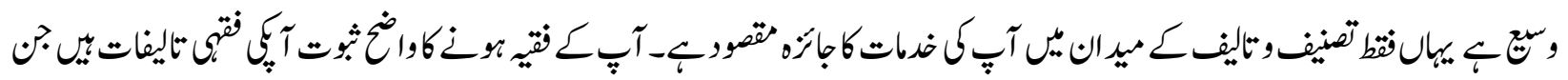

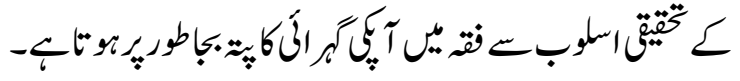

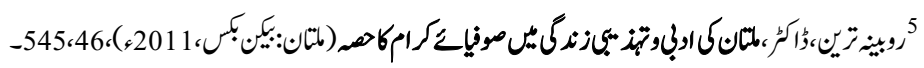

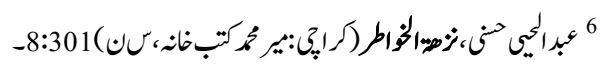
7 


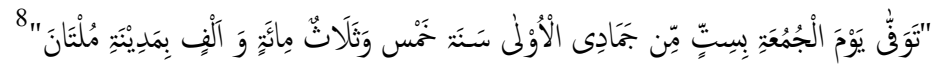

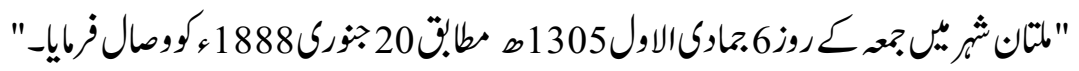

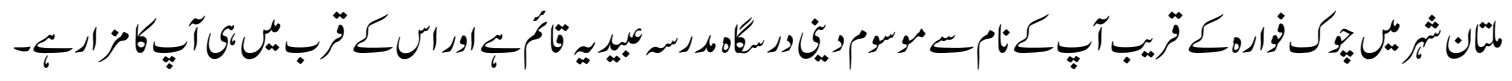

$$
\begin{aligned}
& \text { تصنظ خدطات }
\end{aligned}
$$

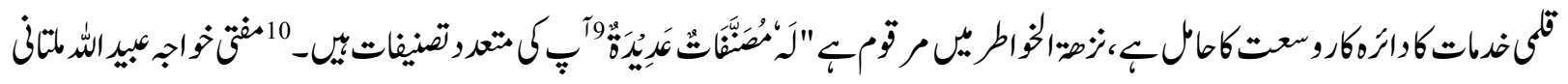

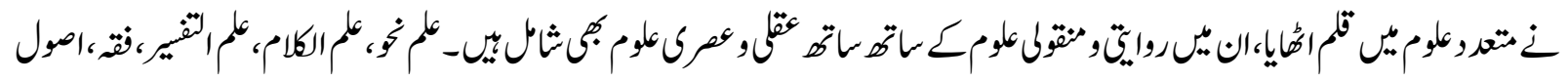

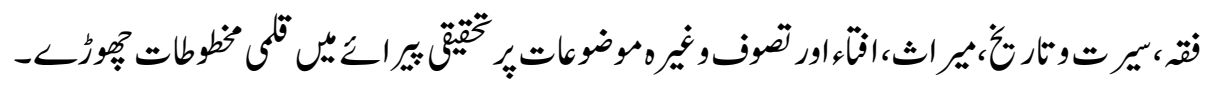

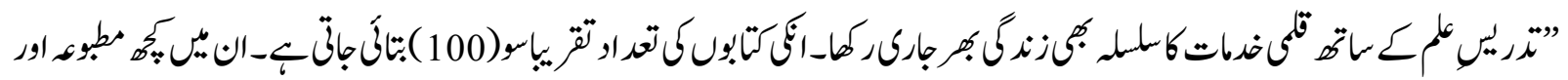

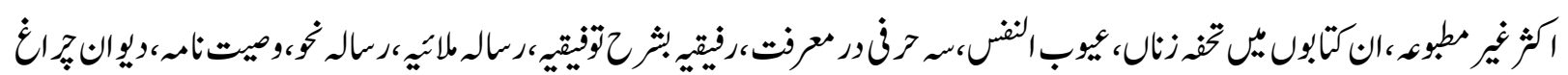

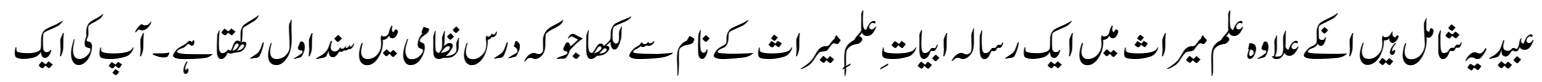

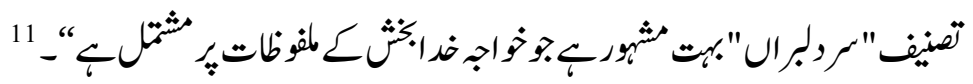

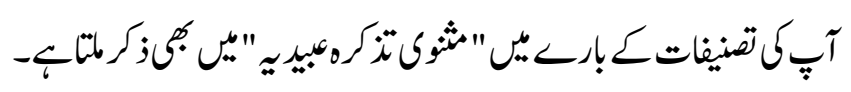

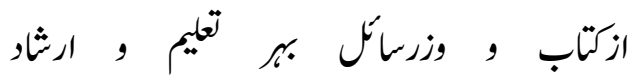

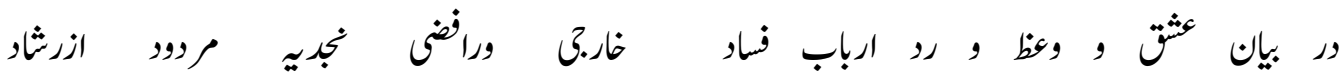

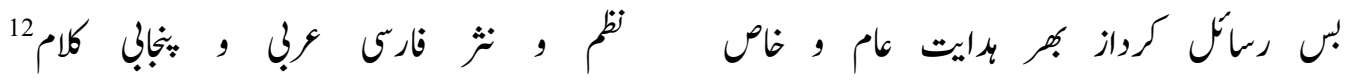

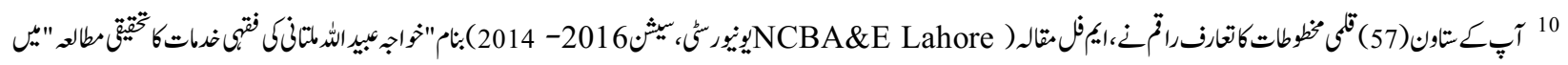
كرواياك11

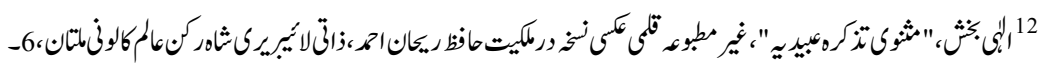




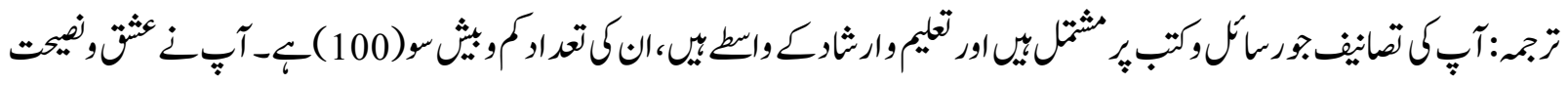

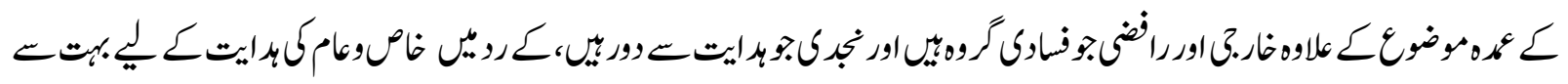

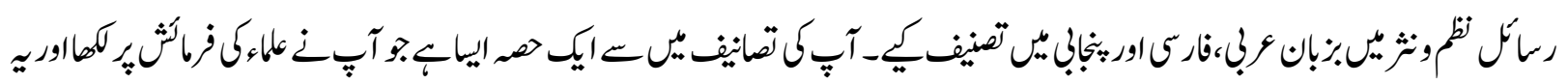

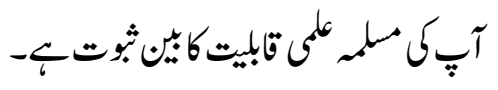

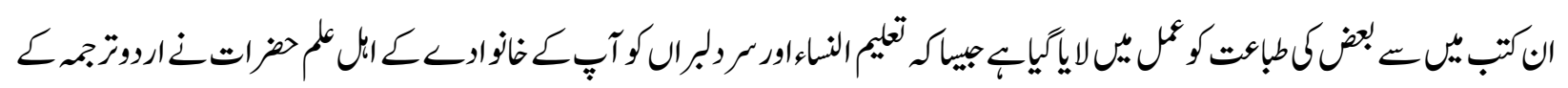

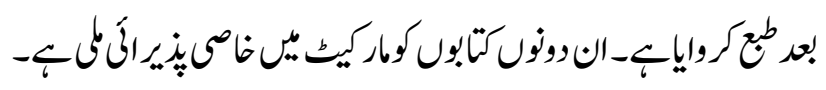

\section{البرمان المققول فى تربيع بنات الرسول}

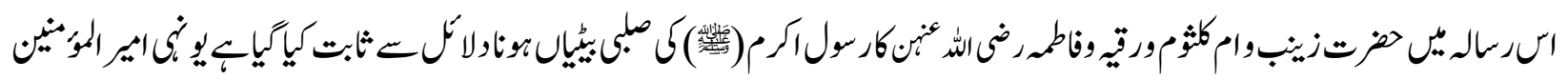

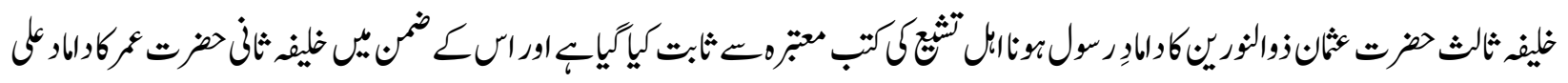

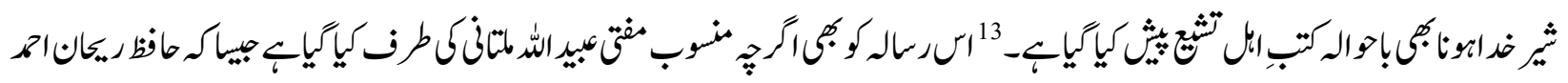

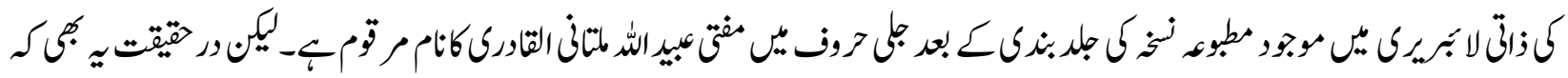

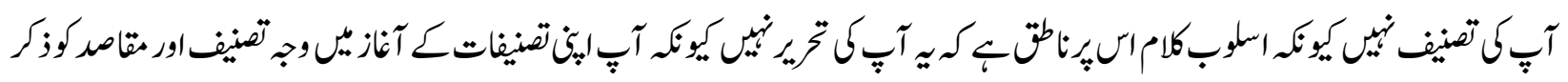

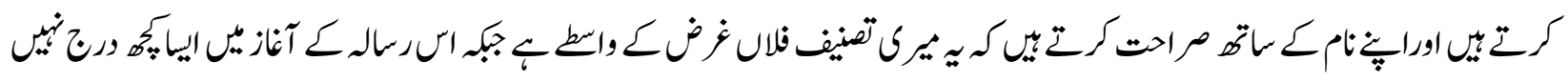

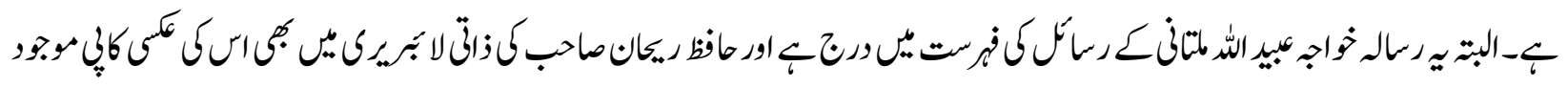

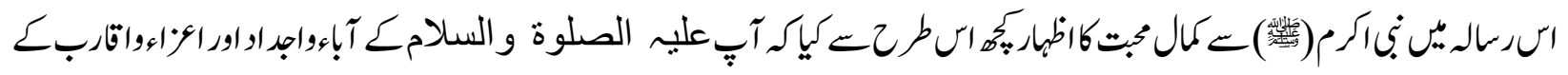

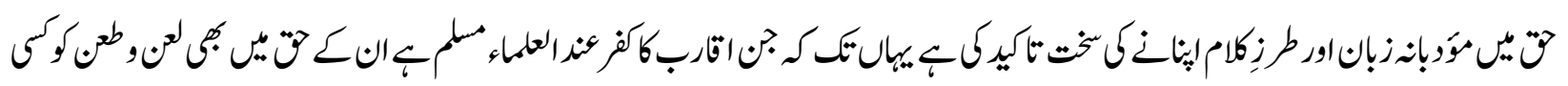

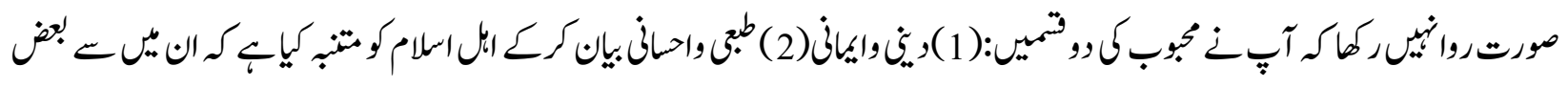

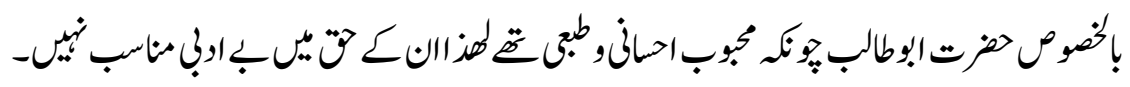

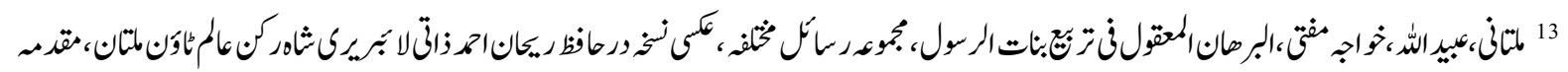




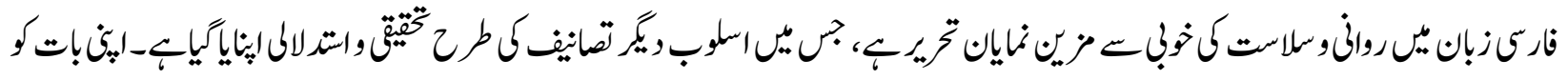

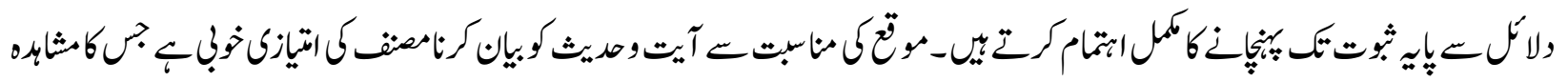

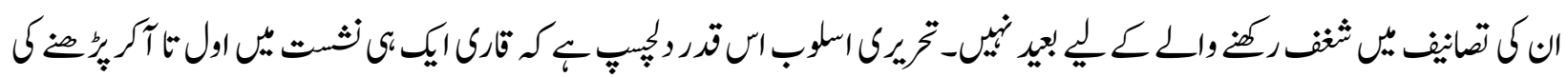

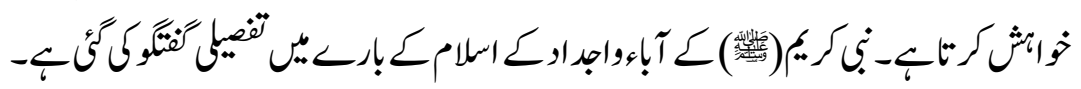

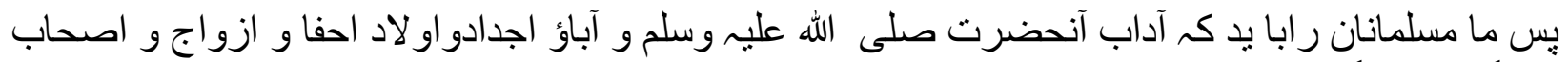

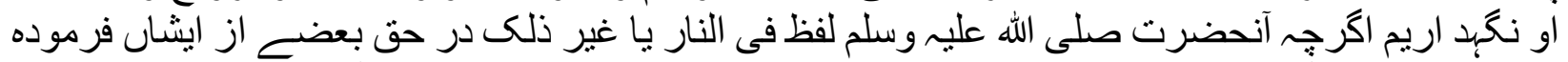

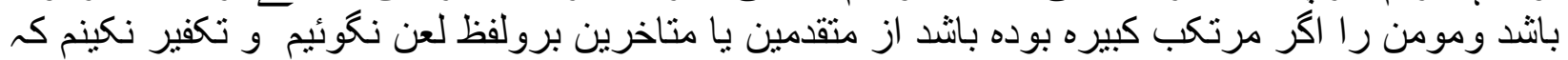

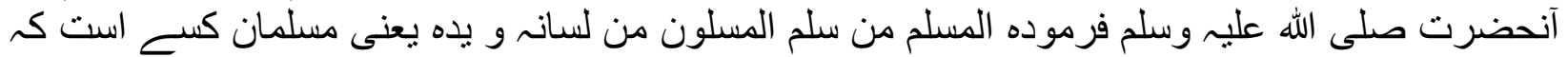

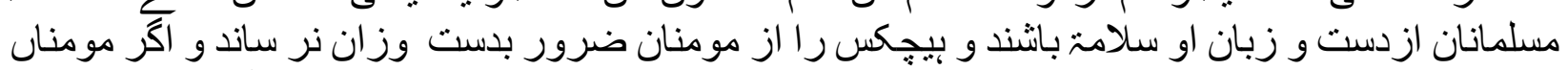

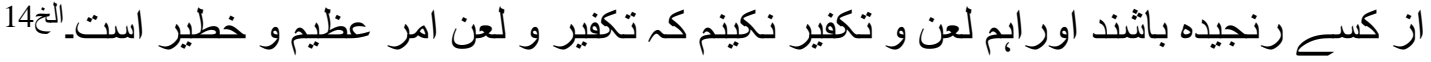

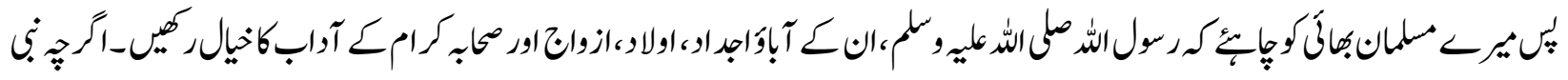

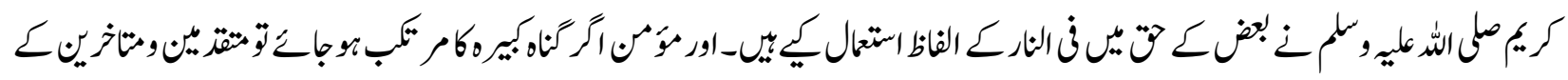

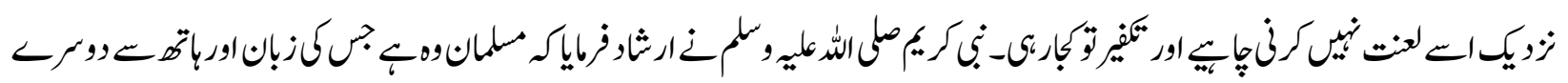

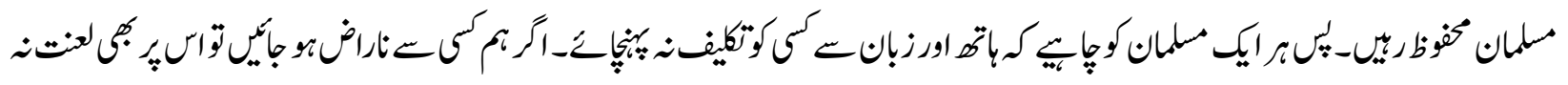

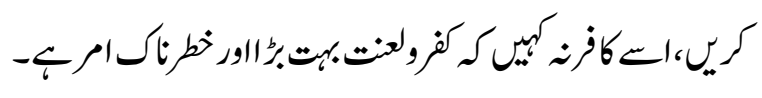

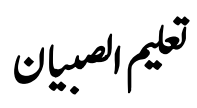

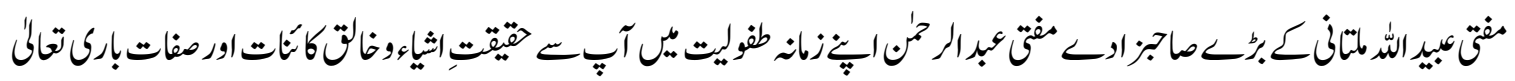

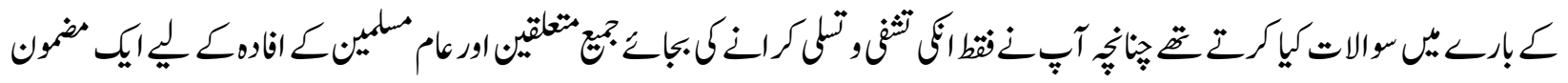

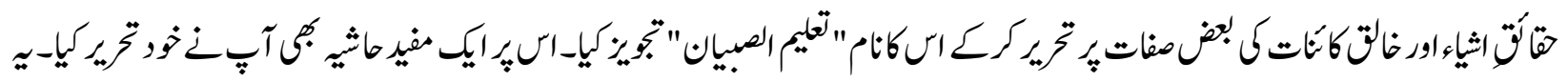

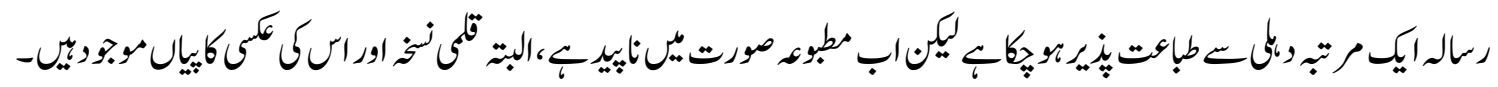

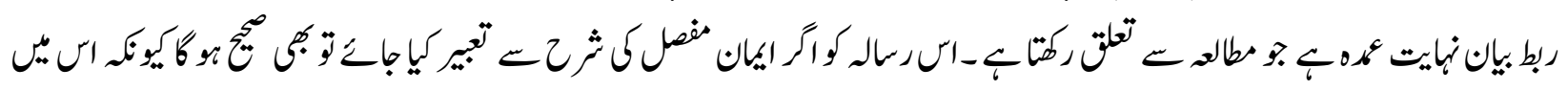

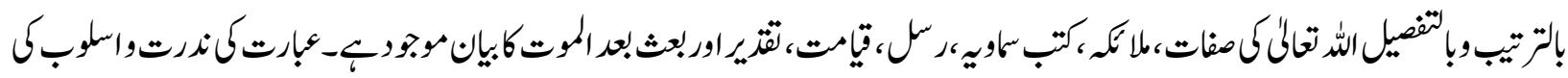

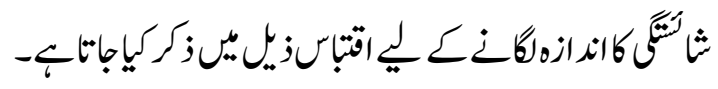

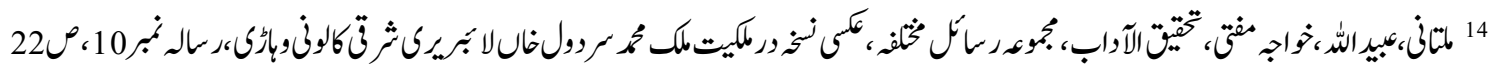




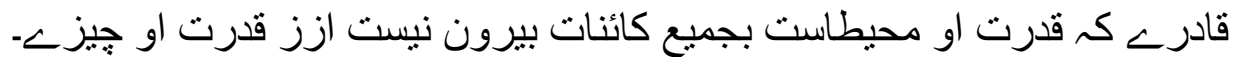

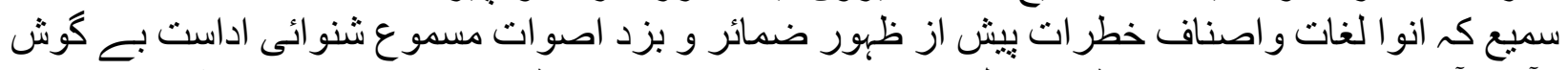

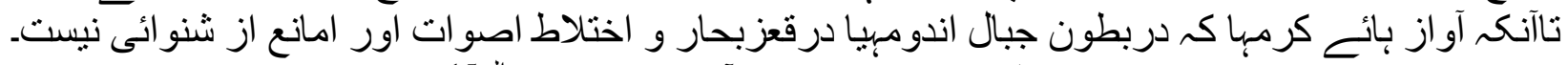

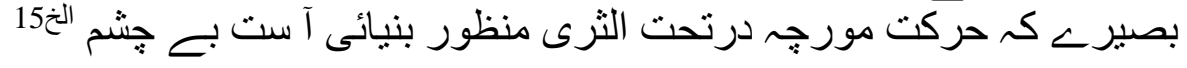

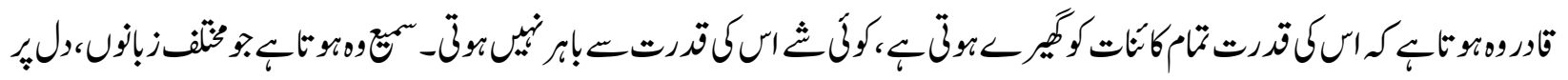

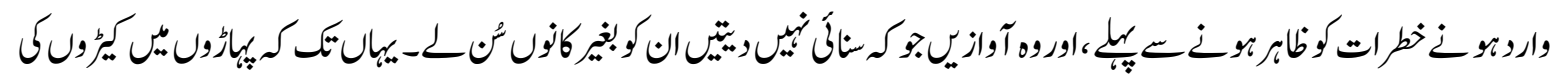

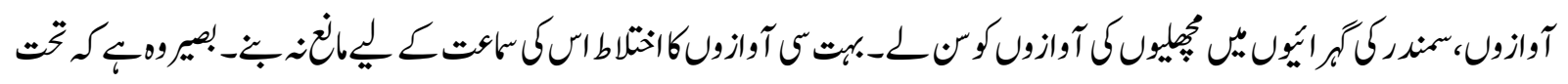

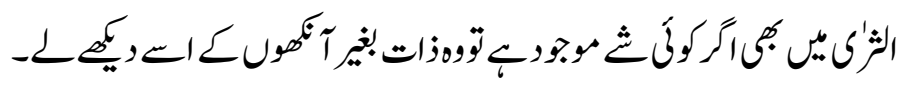

تهليم النصاء

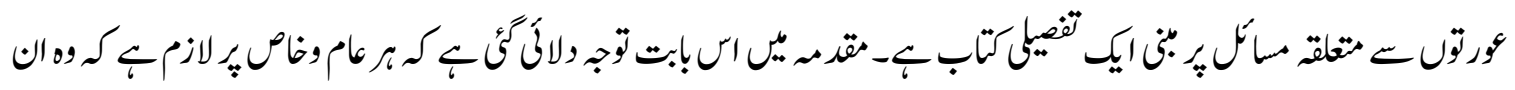

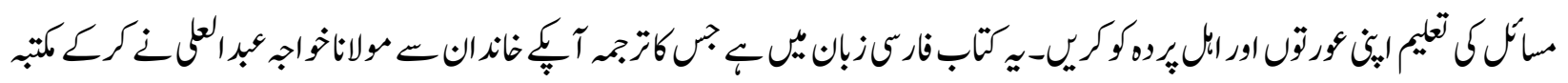

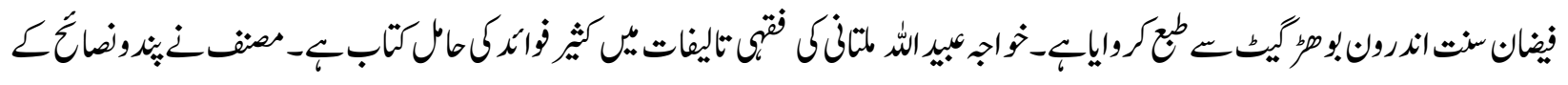

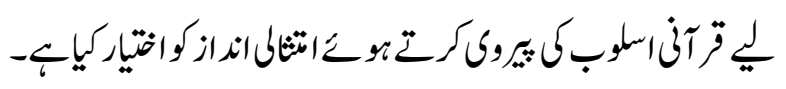

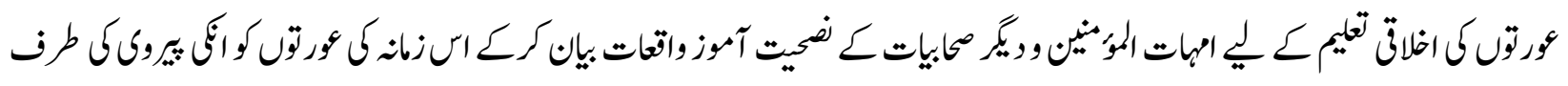

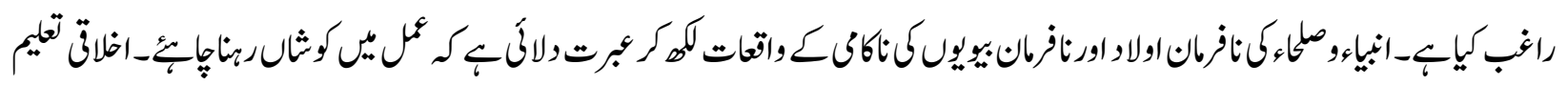

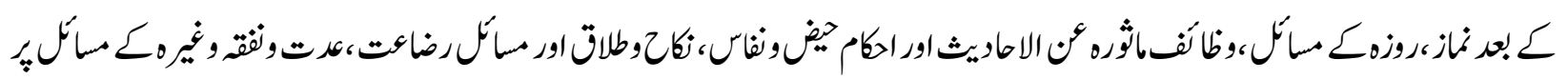

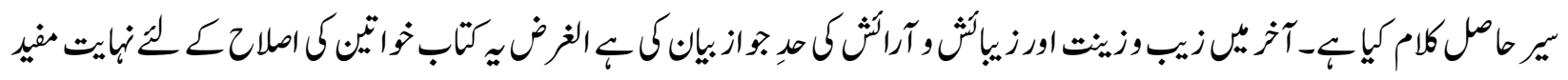

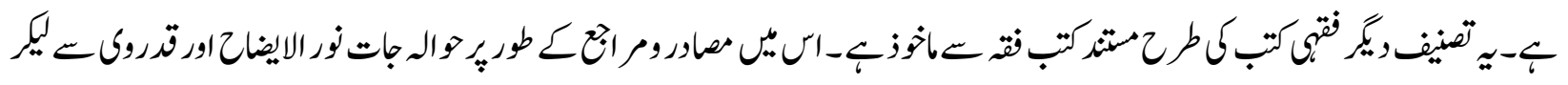

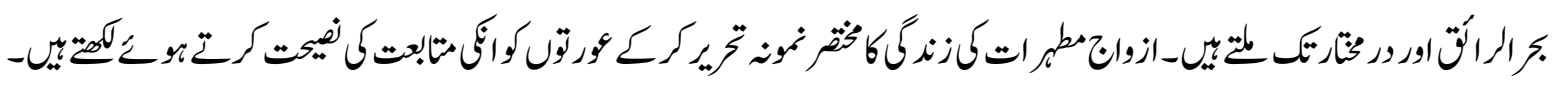

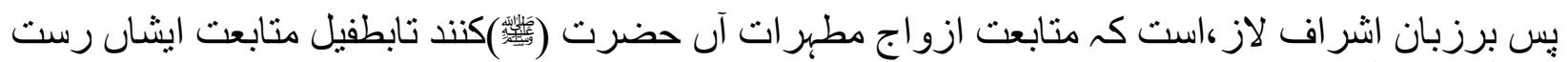

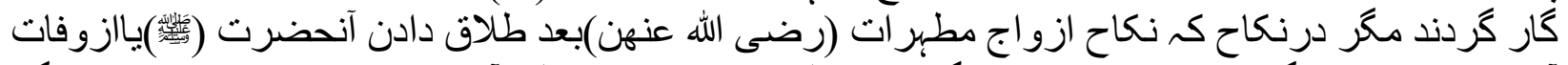
آنحضرت( خوف فتنـ باشد الخ 16

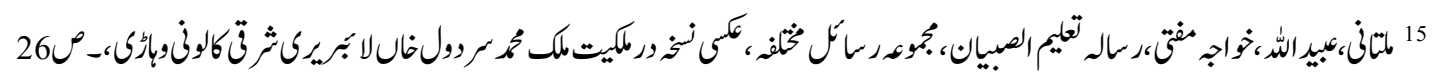

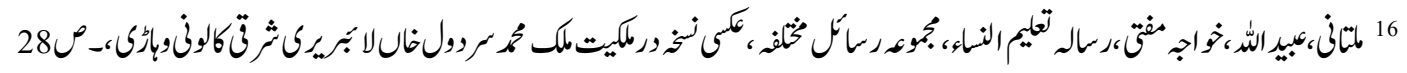




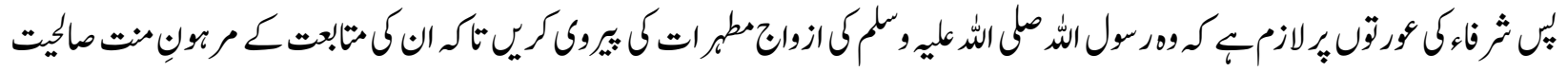

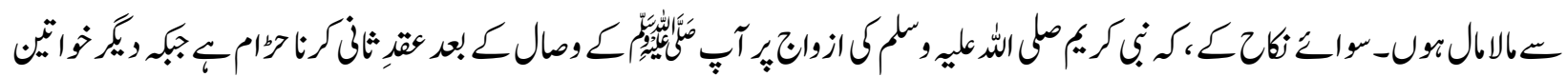

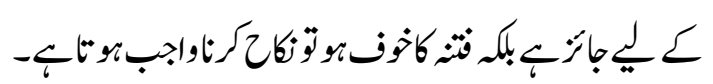

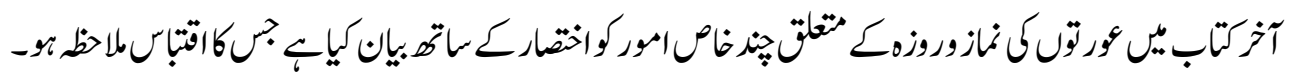

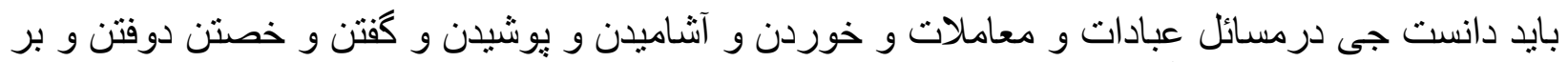

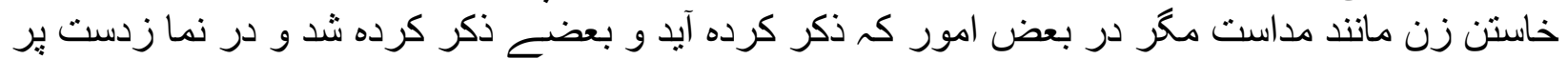

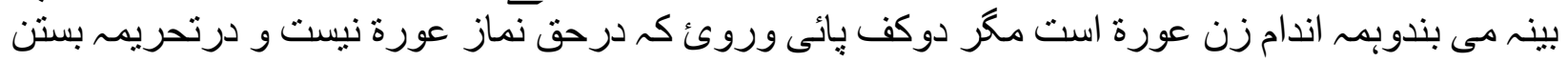

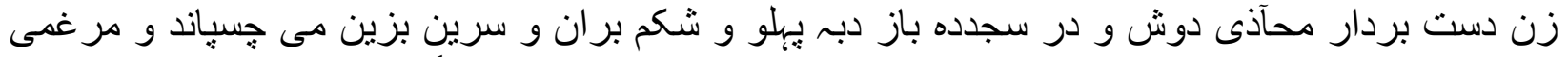

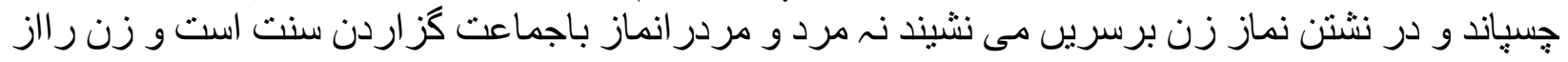

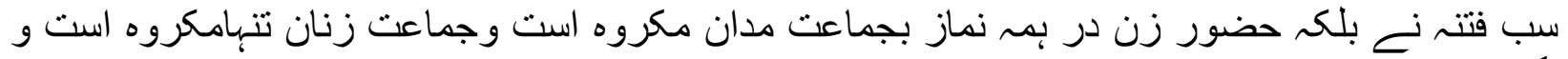

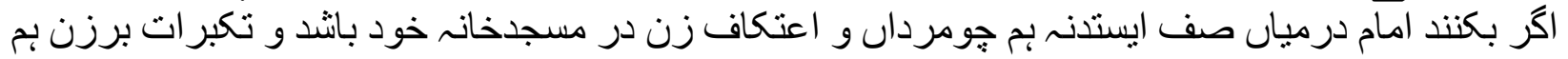

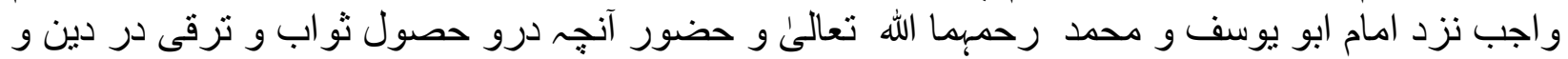

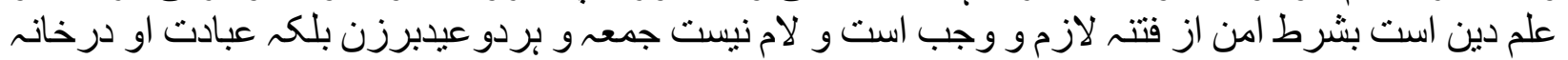

كردن اولى است 17

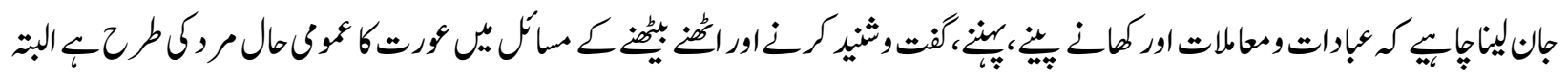

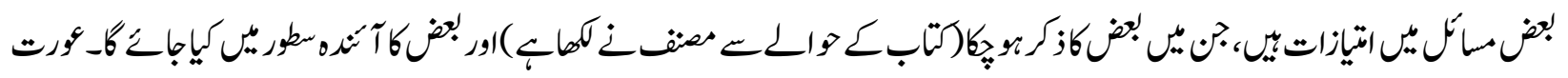

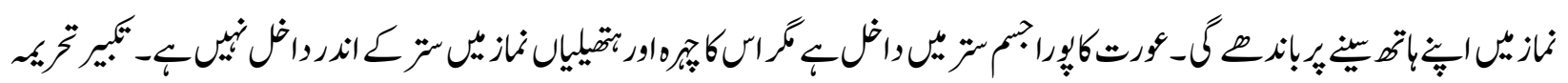

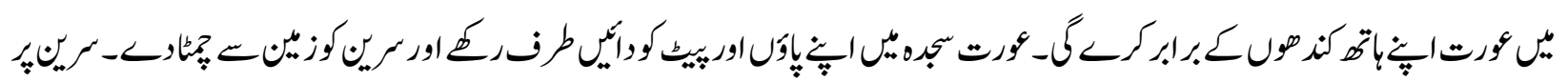

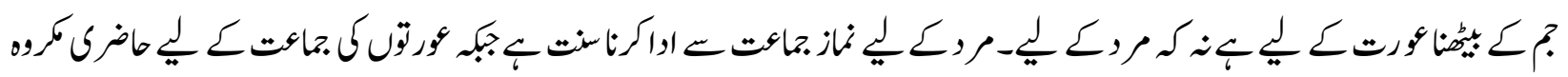

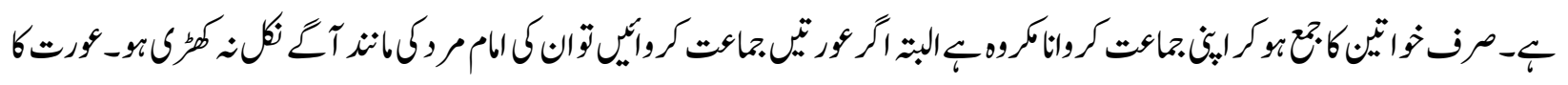

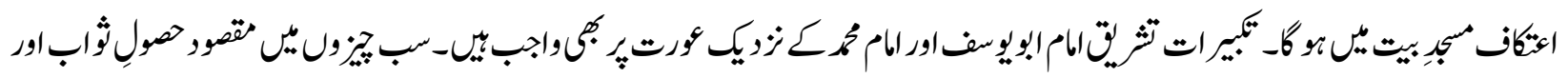

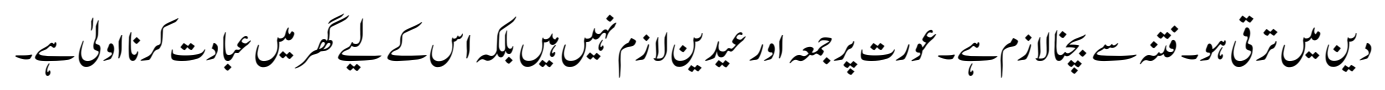

\section{تعين اوقات الصلوة الحمس}

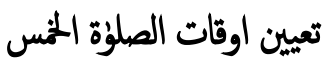

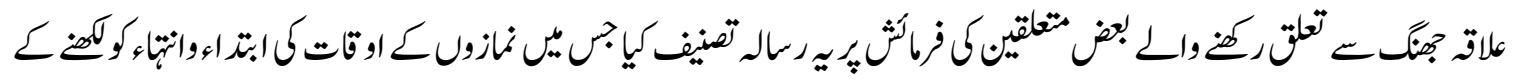

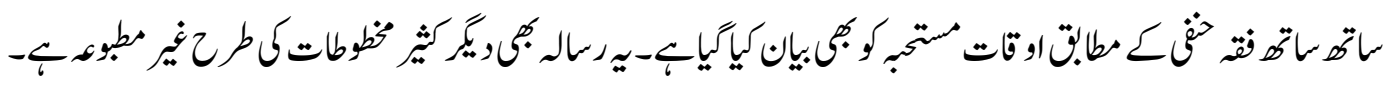

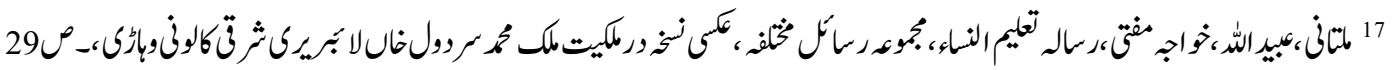




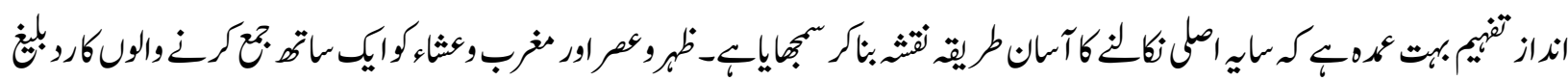

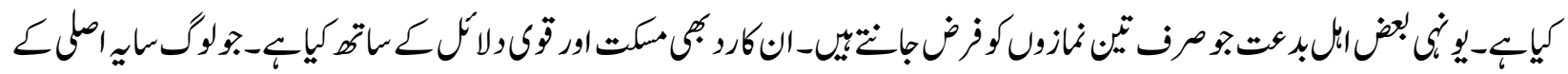

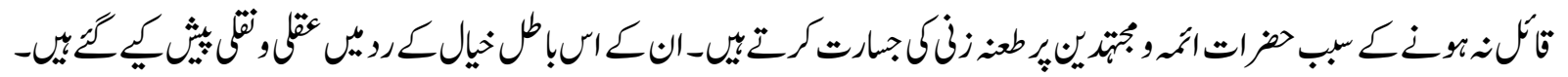

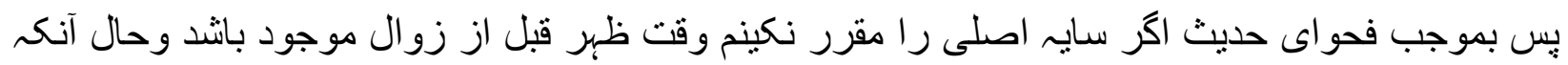

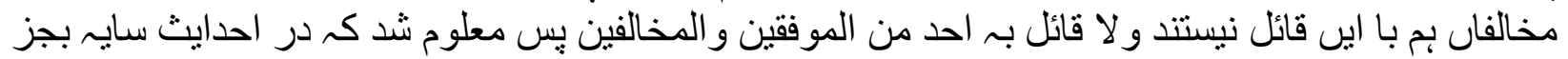

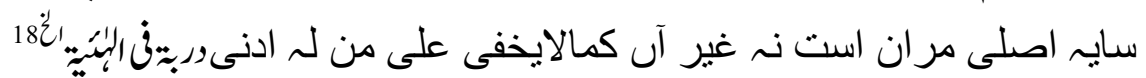

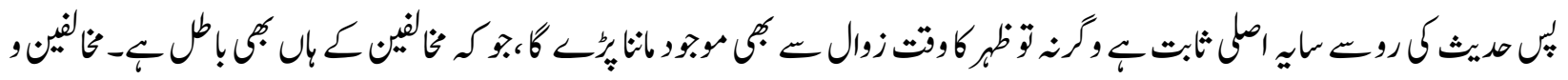

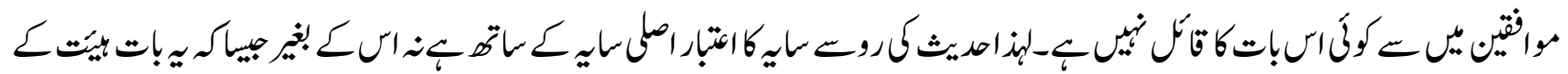

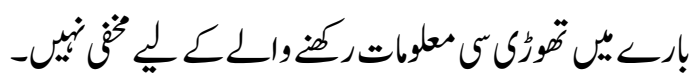

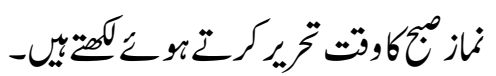

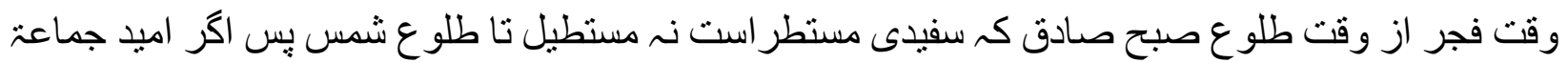

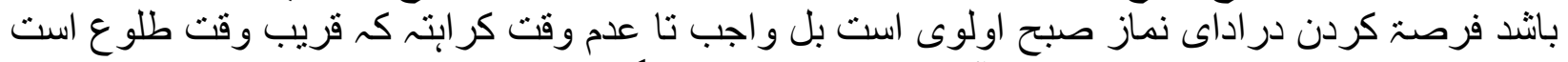

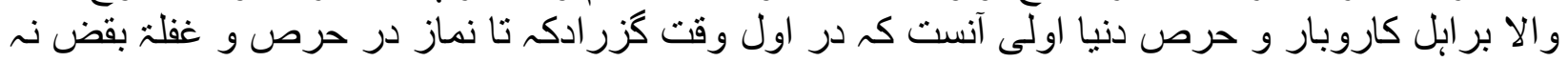

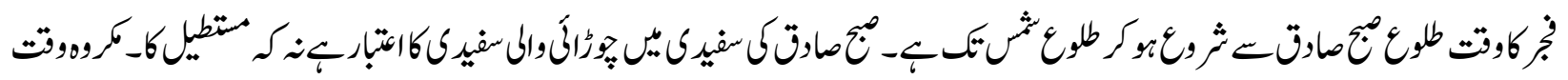

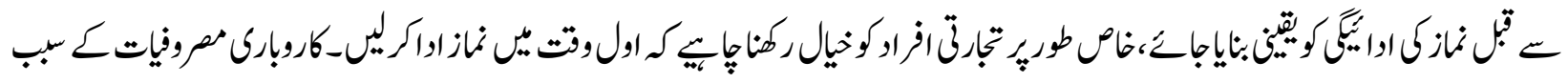

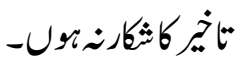

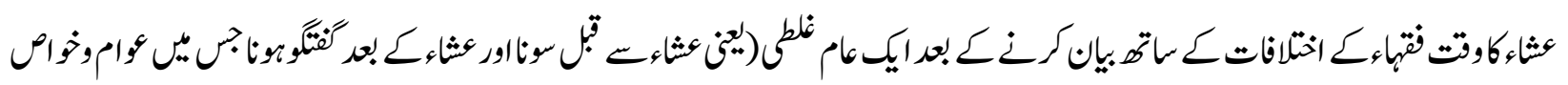

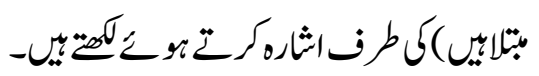

مكروه است قبل از نماز عشاء خفتن و بعد نماز عشاء تحدث_20

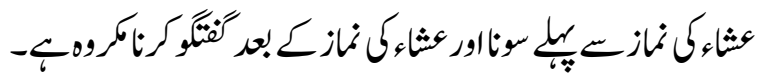

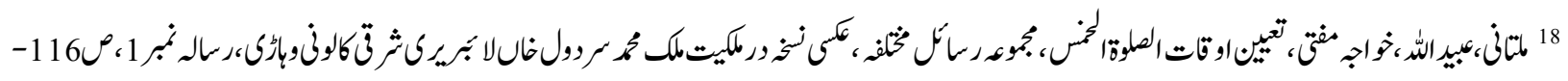

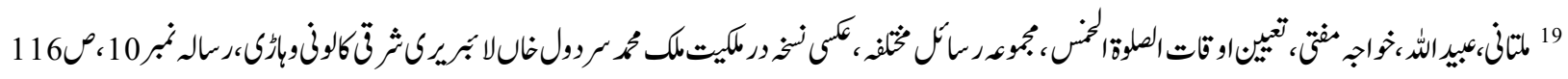

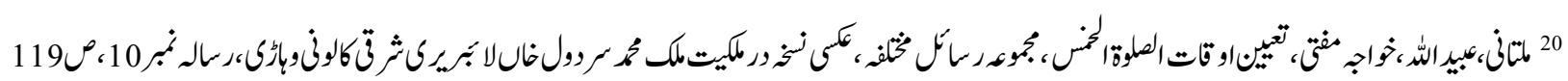




\section{تهنيبوتريفابيات عميراث}

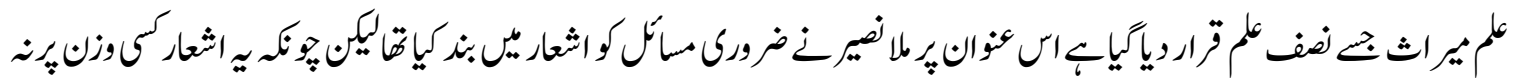

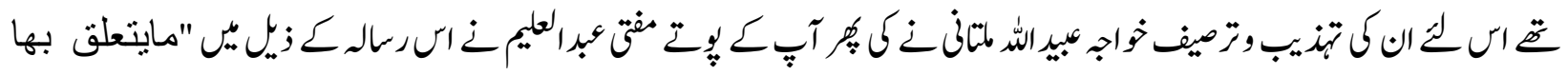

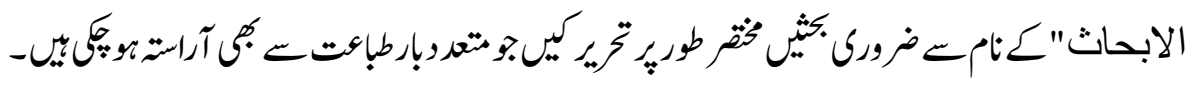

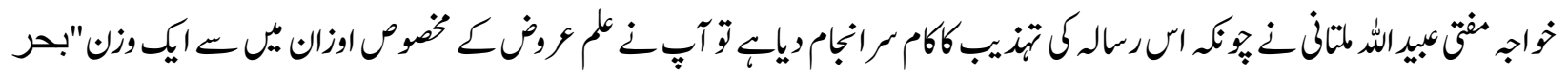

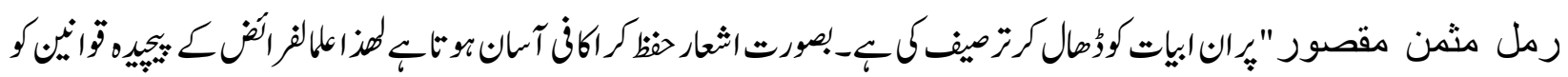

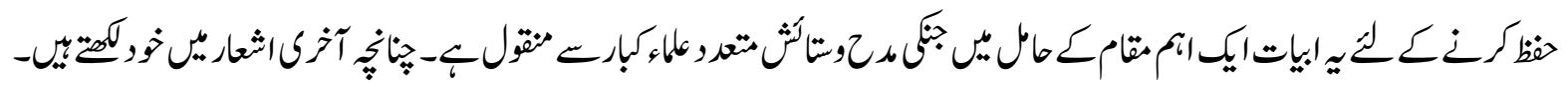

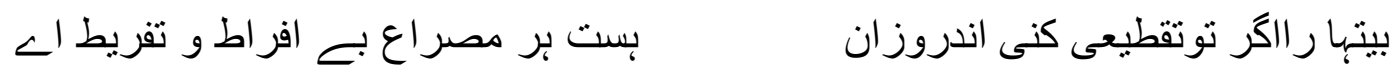

فاعلاتن فاعلاتن فاعلاتن فاعلات كن نظر كردعروض اء بر برفنون درارى مجال

كرداين فاعلاتن فاعلات

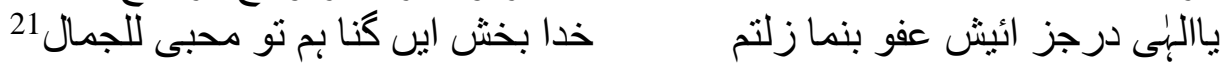

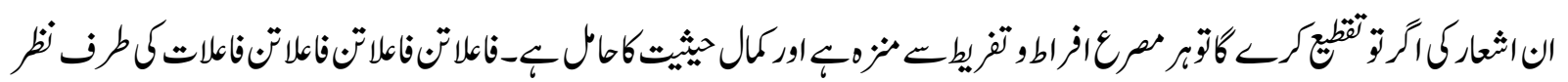

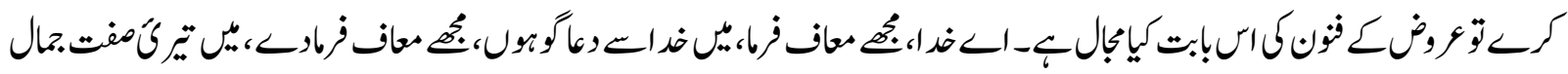

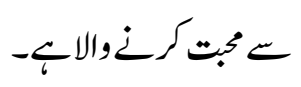

\section{كمثبوفاتمثنيان}

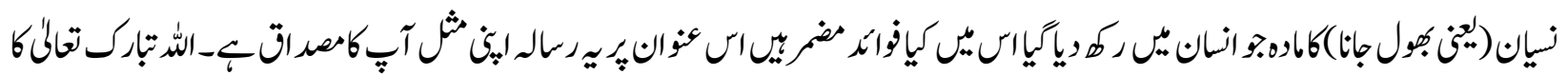

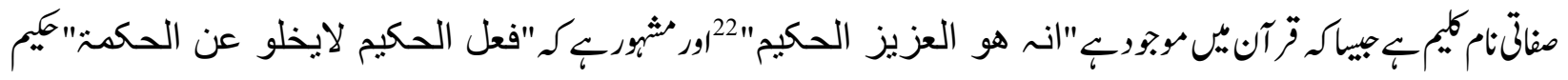

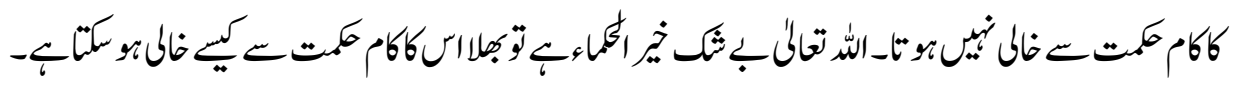

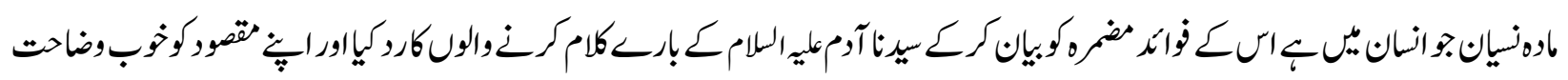

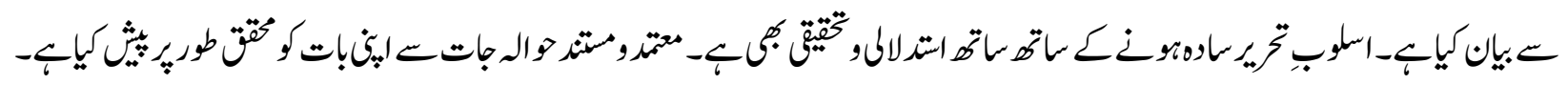

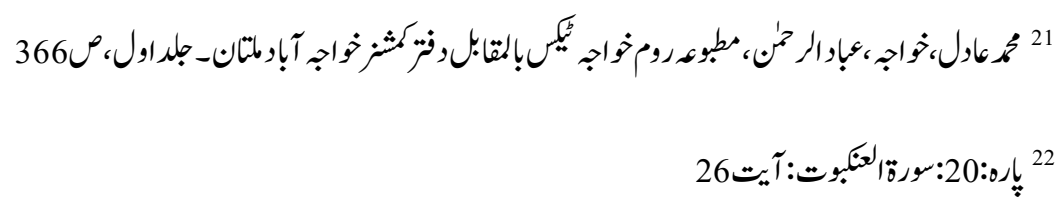




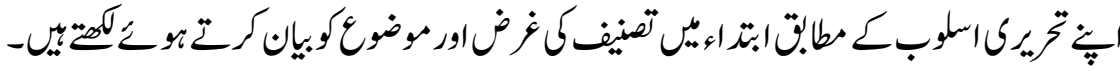

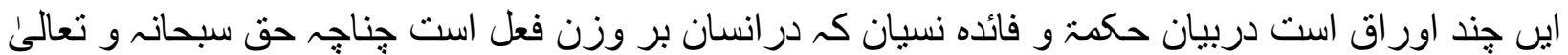

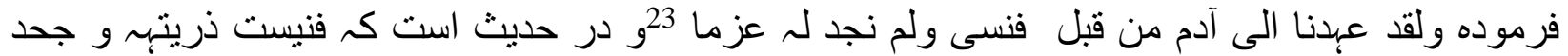

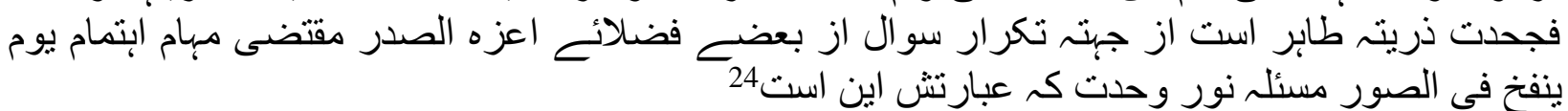

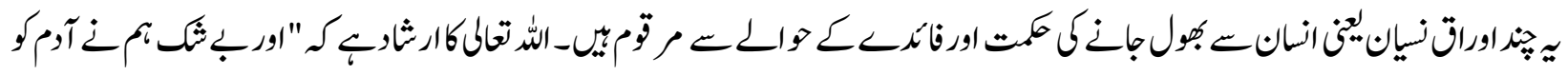

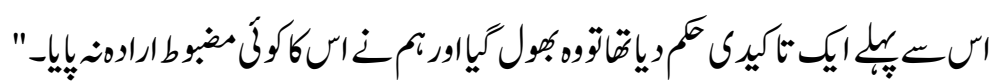

ردالانكار على حلق الراس

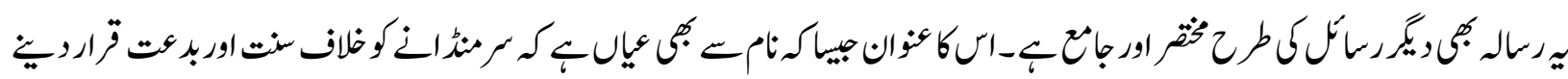

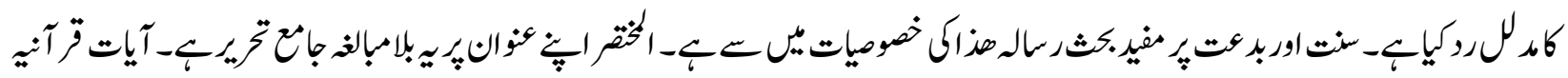

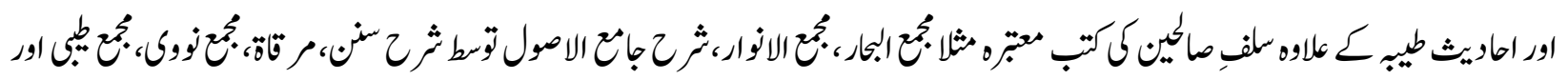

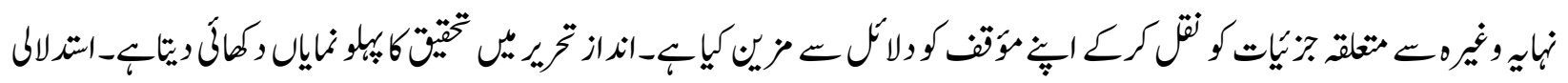

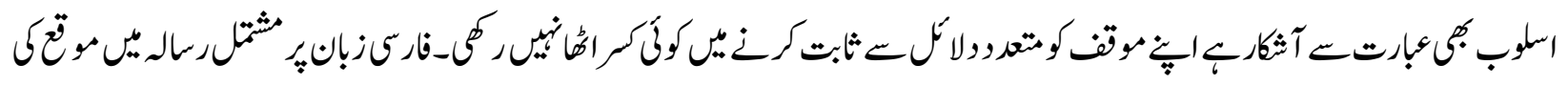

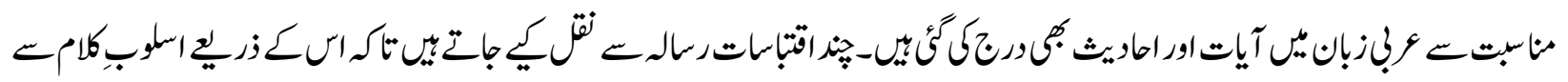

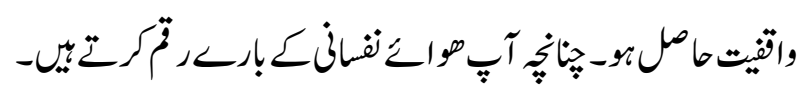

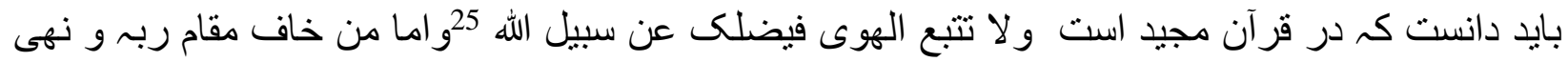

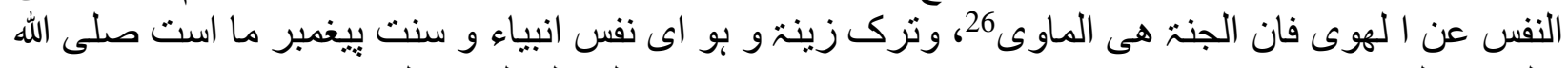

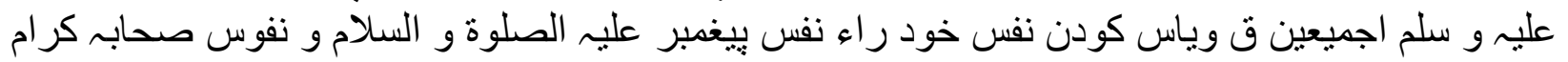

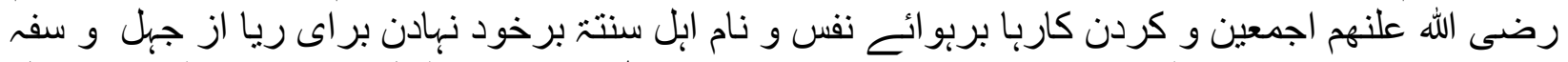

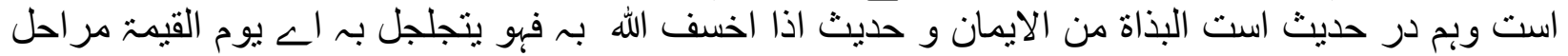

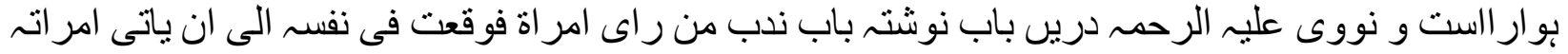

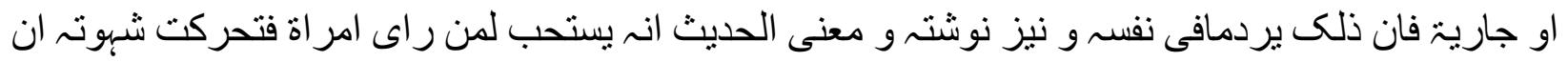

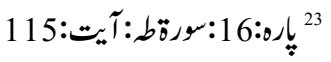

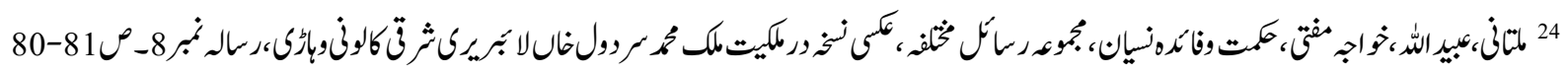

25 ياره230: بورة38:الصار:آيت26

26 باره:30، بورة 79:النازعات، آيت 40-40 
ياتى امر اتـ او جاريت فليو ا قعها ليدفع شهوتت و تسكن نفسه و يجمع على مابو يصدده قولـ صلى الله عليه وسلم ان المر اة تقبل فى صورة الثنيطان و تدبر في صورة شئر شيطان 27

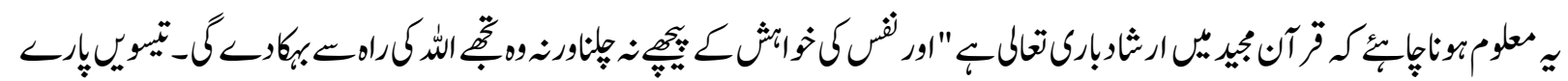

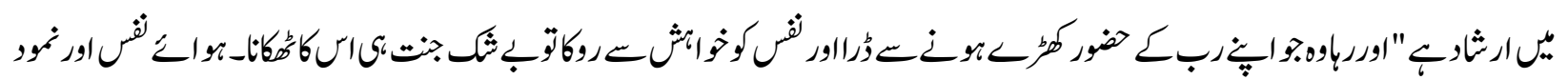

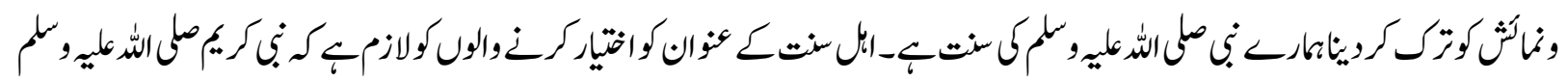

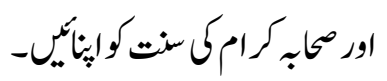

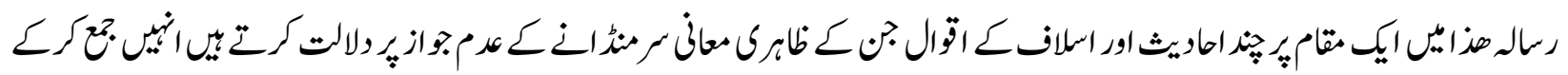

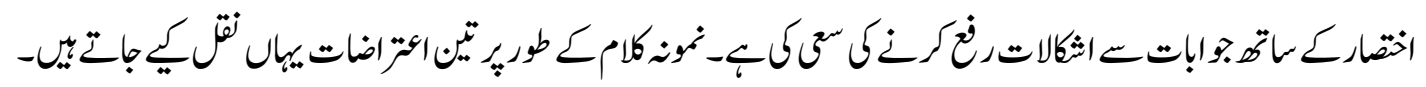

و اما قول صلى الله عليه وسلم ليس منا صلق او حلق فى الجمع اى ليس من ابل سنتنا من حلق شعره

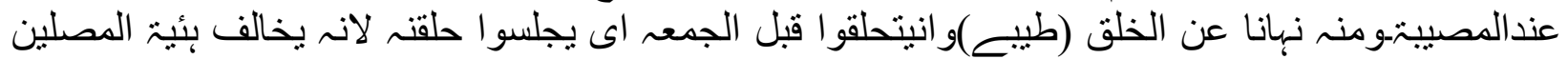

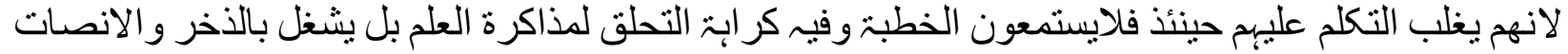

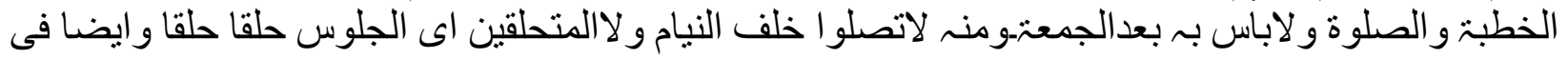

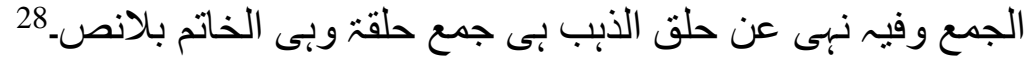

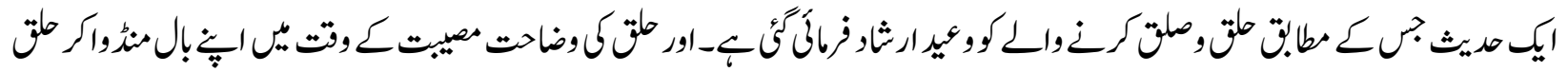

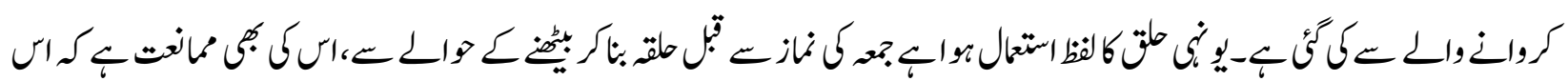

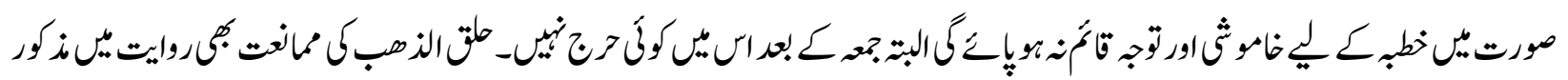

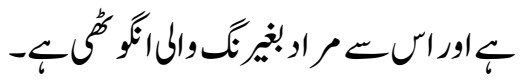

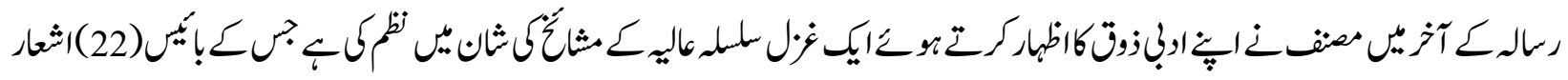

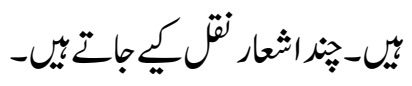

$$
\begin{aligned}
& \text { جنان حير ان دمست آن نحارند كـ از نقش ونكارى يادارند }
\end{aligned}
$$

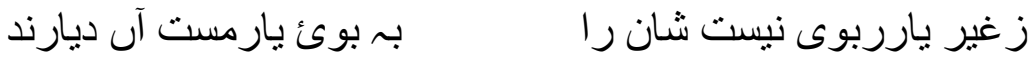

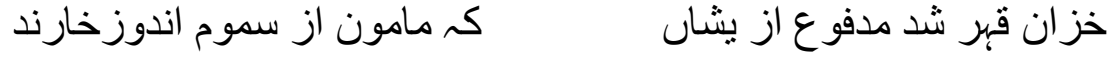

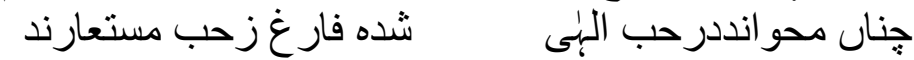

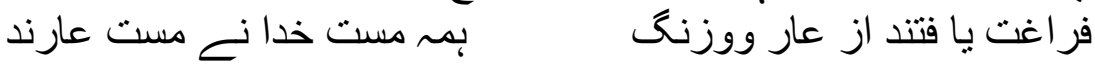

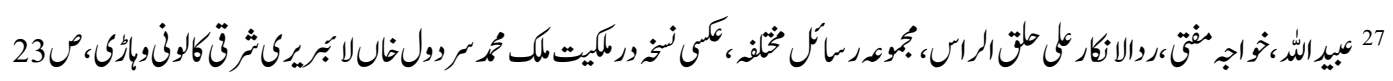

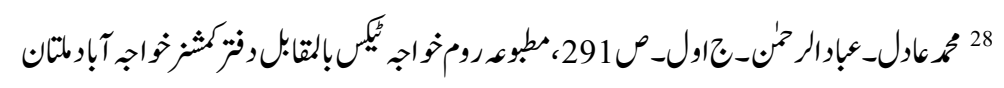




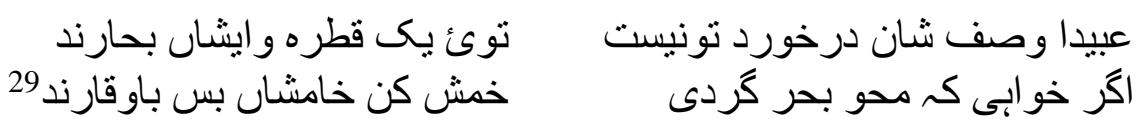

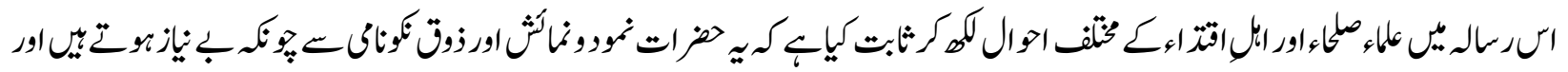

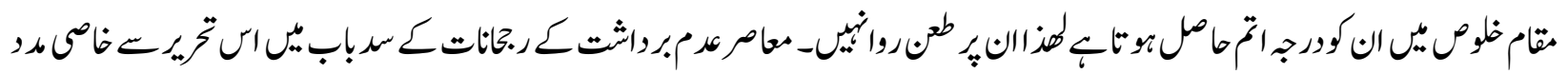

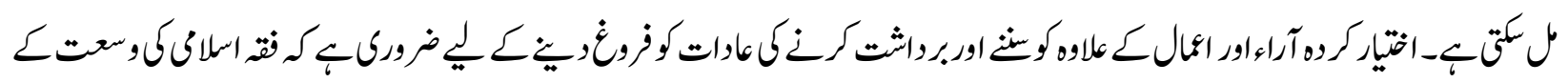

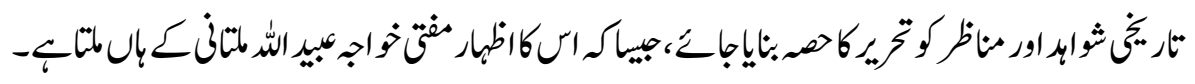

رالـانئي

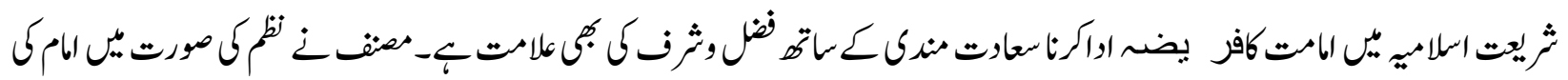

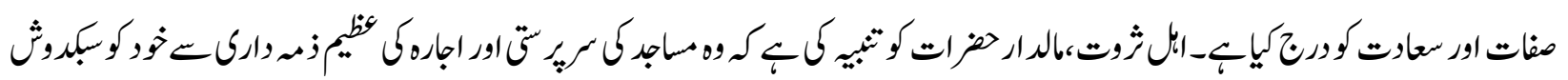

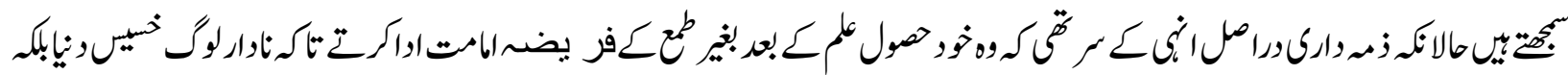

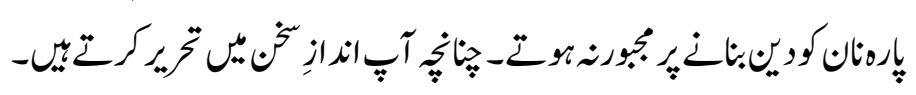

واسط طمع نماز يّز هاوـا

حاجت كبين نه ركه اوهو

قارى بهى آواز خوش بيغمبرنال شبير

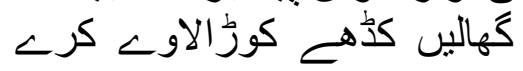

مال يتيمان عاجز ان كهاو بـ دل و ع اوس

ذذيون اسداجرم بـ بهار اكبنا بهى سلام

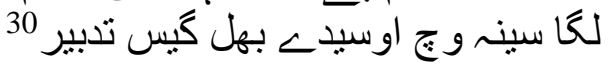

امام ج) طالب دنيا بوو ـ وظيفر اس حرام

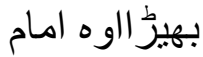

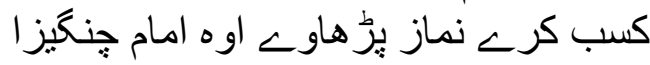

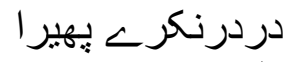

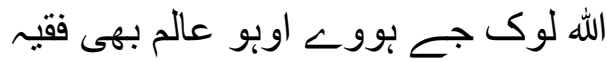

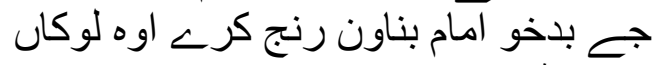

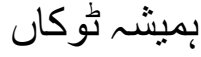

يم امام خدا نـ بهانويس دشمن لوكان اوه

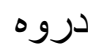

يم امام شيطان حقيقى ناهيس ايم امام

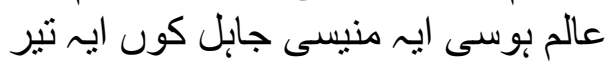

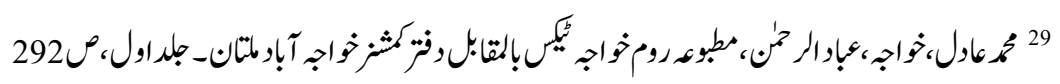

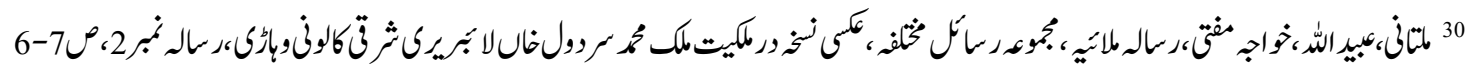




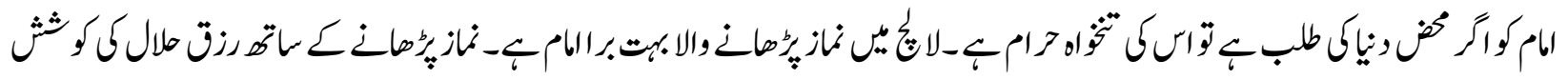

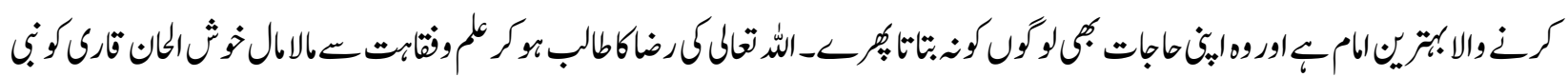

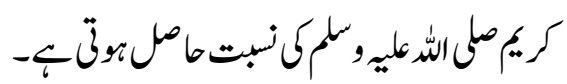

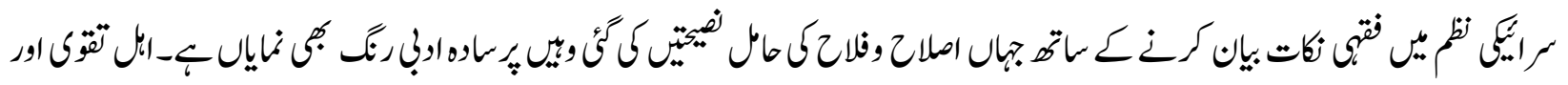

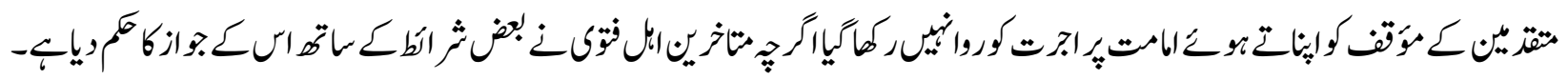

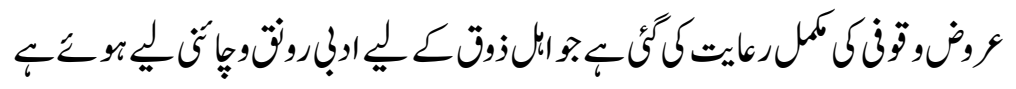

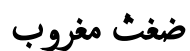

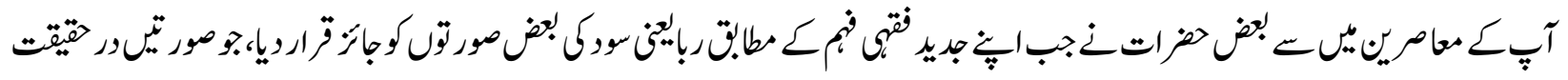

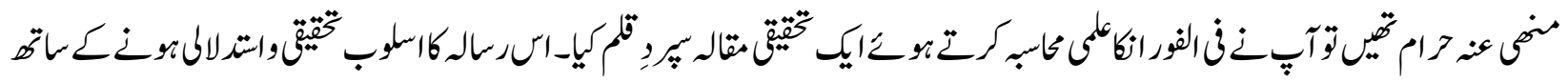

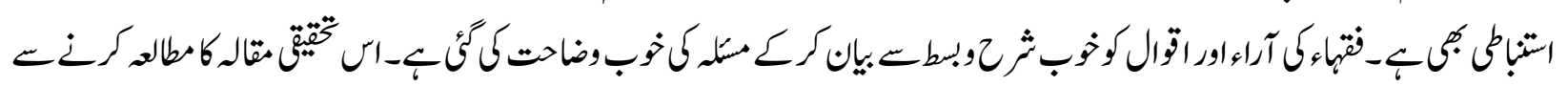

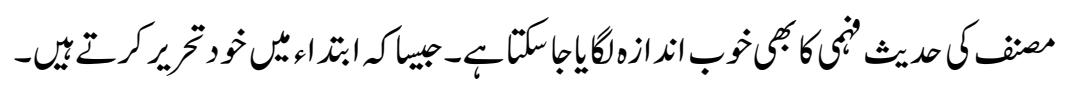

وقد سمعت ان بعض العلماء قد سعو ا فى تحليل نوع من الربوا و بو المنهى عن بقول تعالئ" لا تاكلوا الربو ا

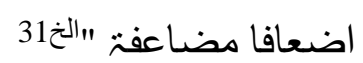

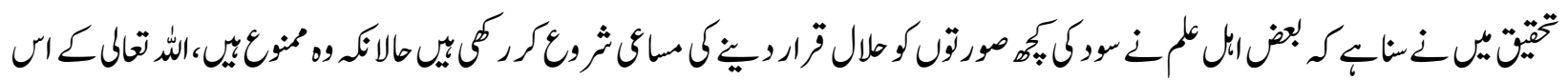

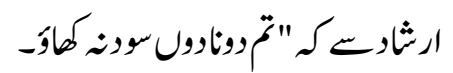

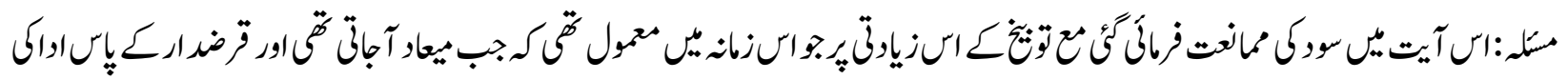

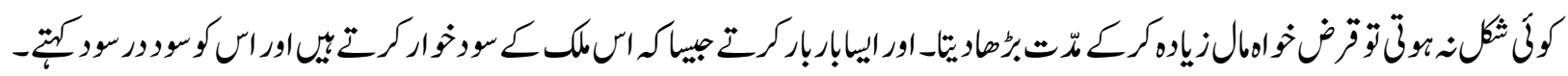

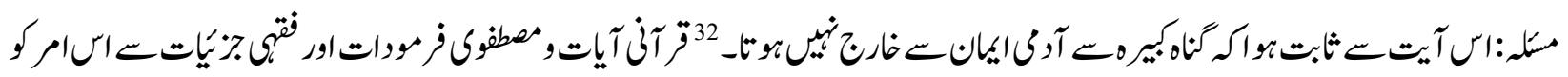

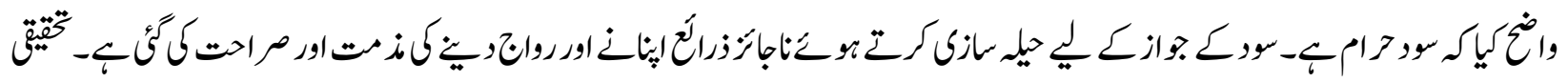

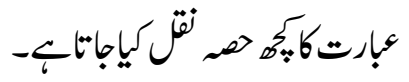

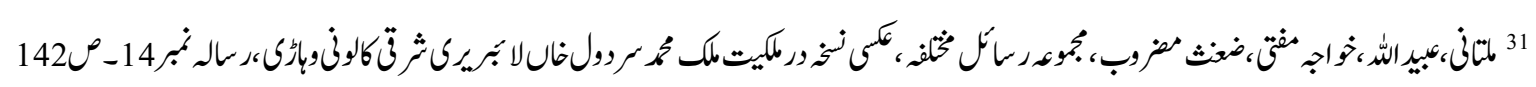

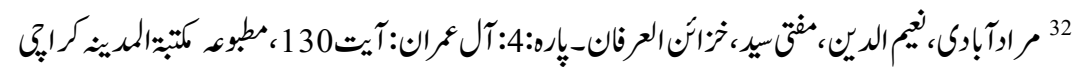




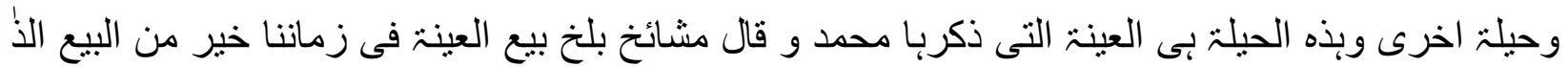

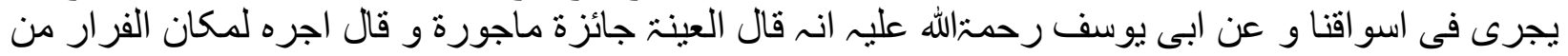

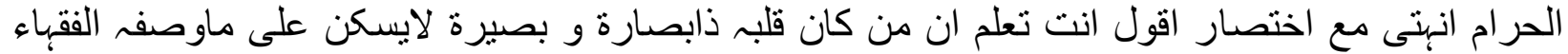

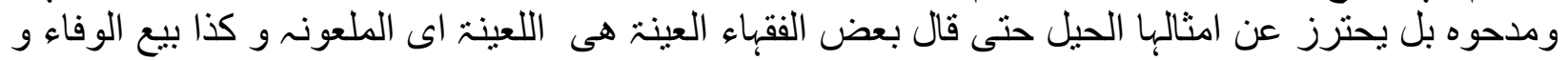

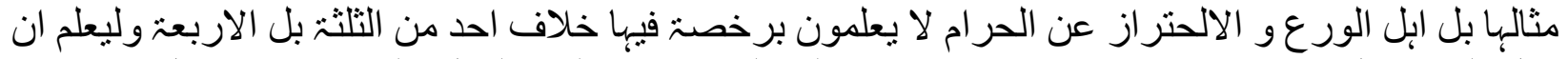

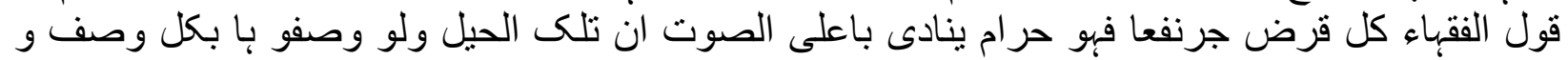

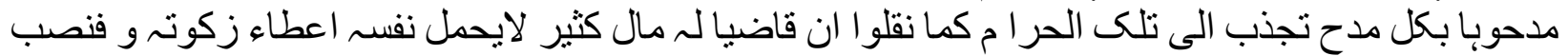

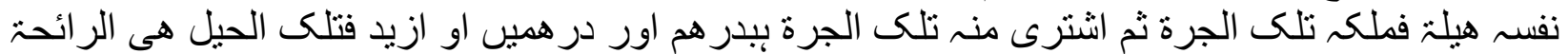

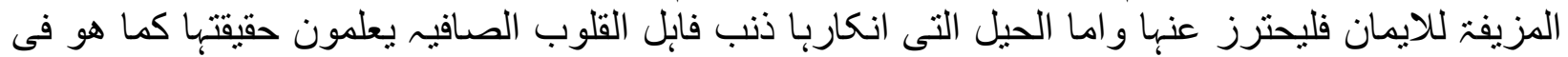

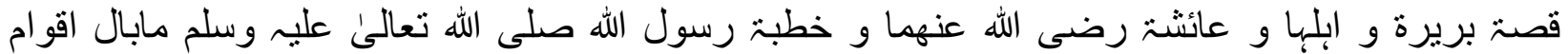
يشترطون شروطا ليست في كتاب الله الخئ

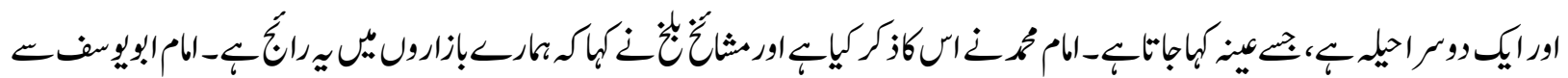

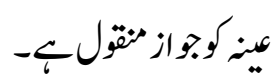

قصائد عبيدير

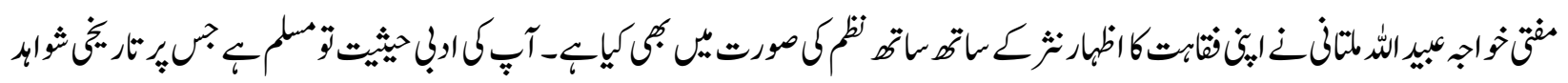

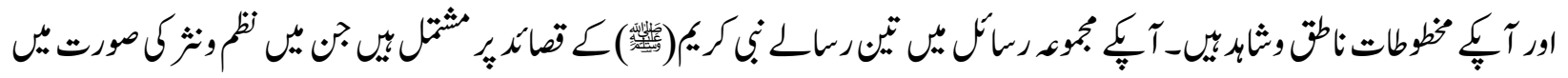

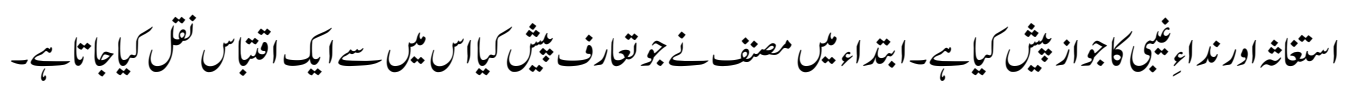

بسم الله الرحمن الرحيم_اللهم لكى الحمد اليى المشتكى وانت المستعان و السلام عليك ايهاالنبى و رحمنالله و

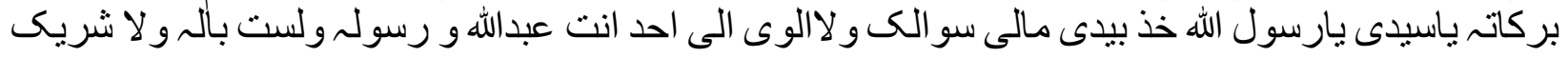

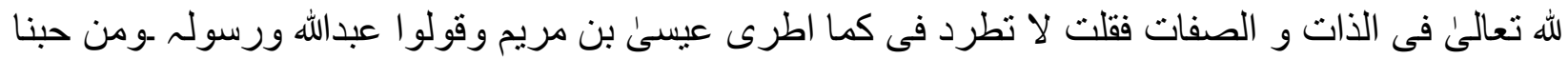

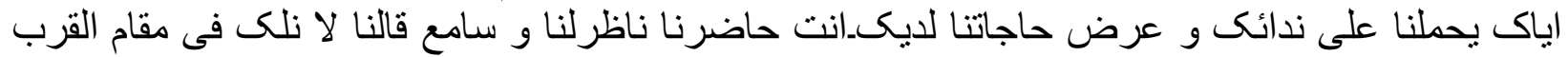

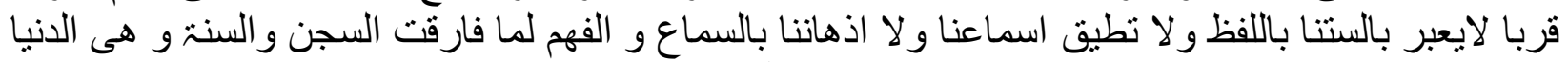

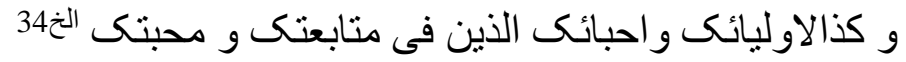

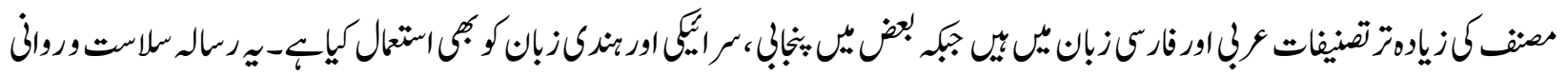

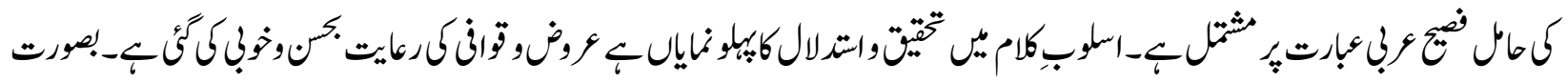

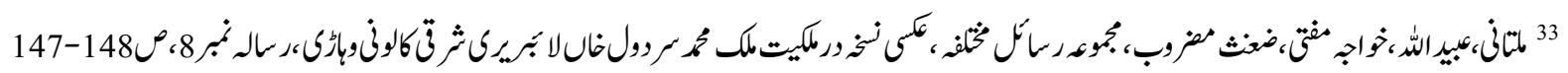

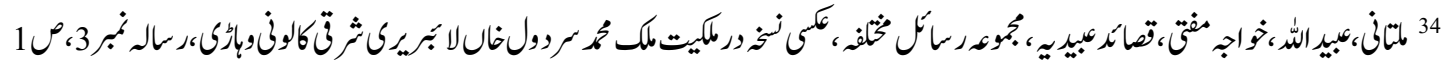




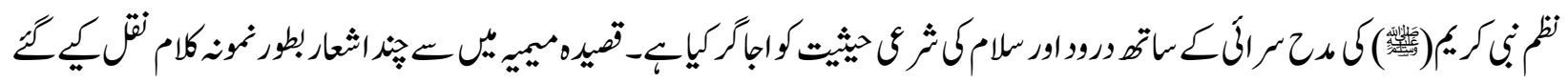
$-4$

رفع ذكرك فى الخلائق فانتظم فى الفر ائض و النو لفر افل واحتكم بل شفاء فير من كل السقم للقلوب من المعاصى ون اللمن المّم فى الصلؤة و فى الدعاء الدعاهئ الملثزم طعم ايمان وكسار الصنم فع فاء الصن
يارسول الله كاطبى الأل

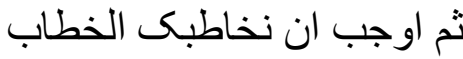
يارسول الله ذكرك مانع يارسول الله ذكرك مونس دئس يارسول الله ذكرك ول اجب لئب يارسول الله حبك فى القلوب

\section{قول فصل فى البيعز والساع و شرح مفصل}

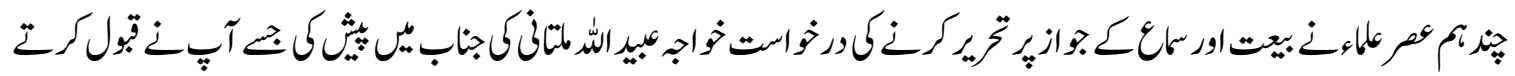

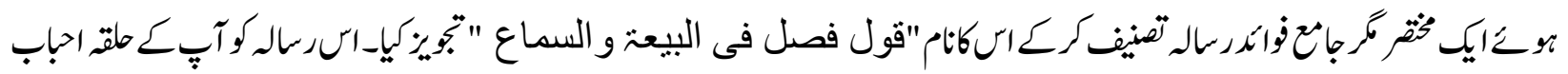

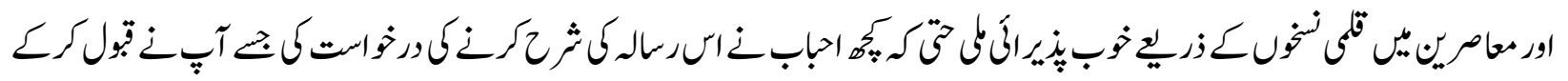

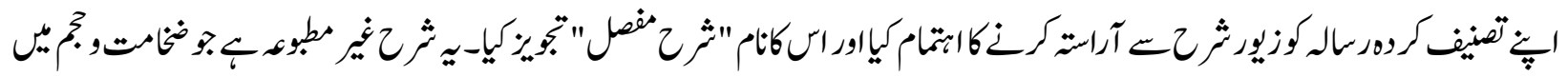

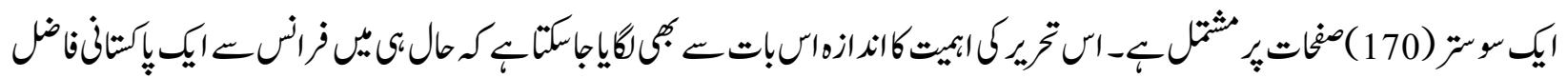

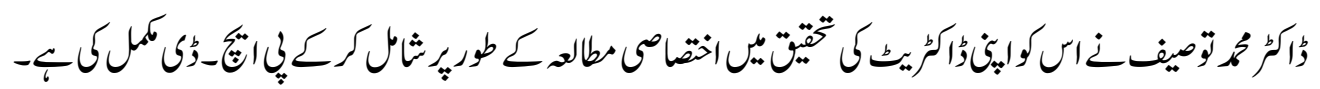

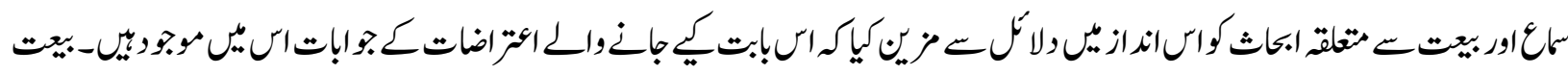

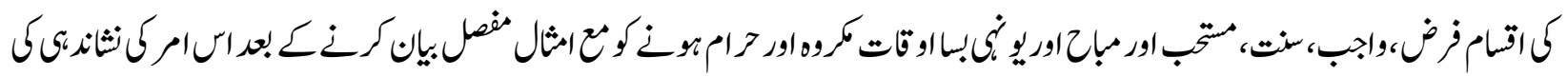

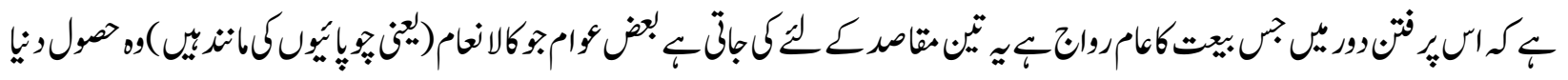

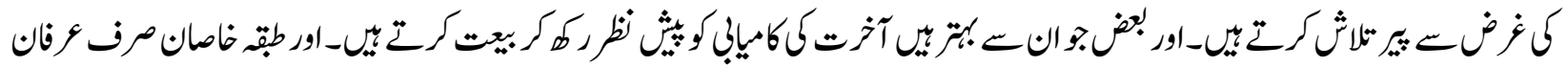

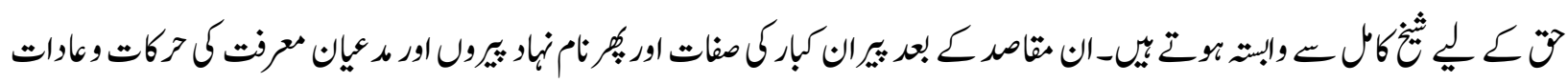

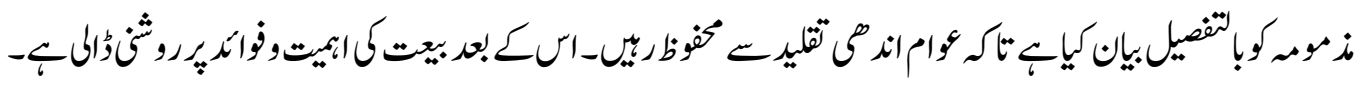

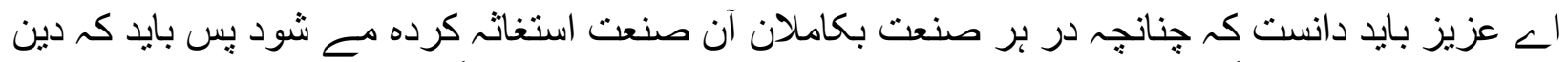

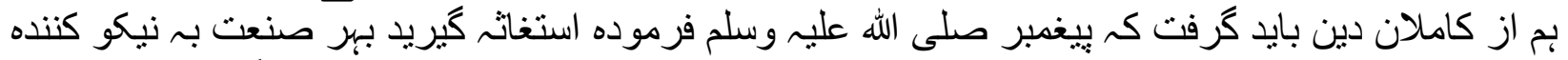

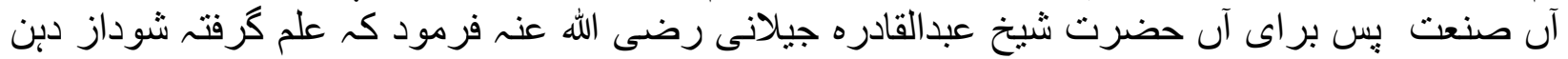
اولياء نـ از دفترباـانتهى آنى 35

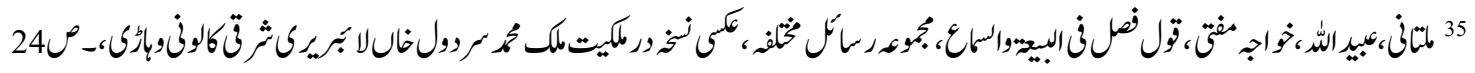




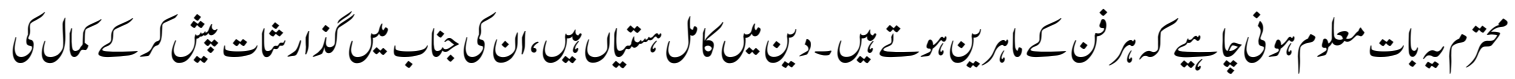

راه كواينانإِ

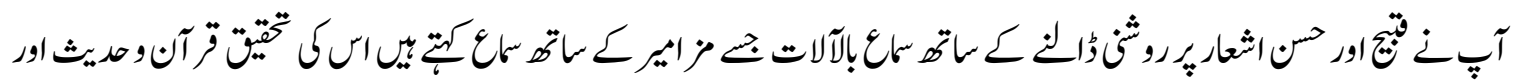

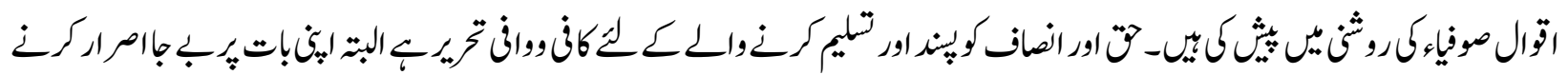

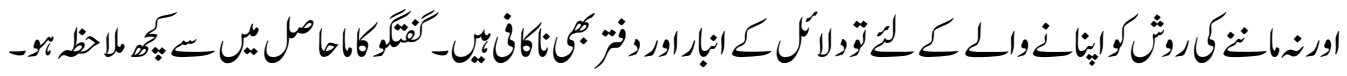

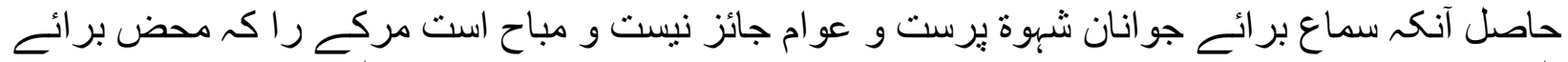

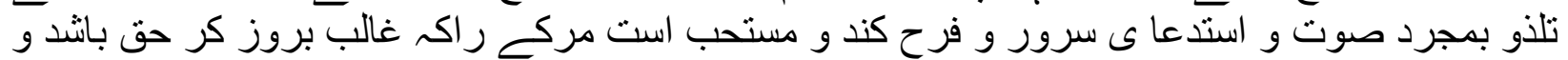

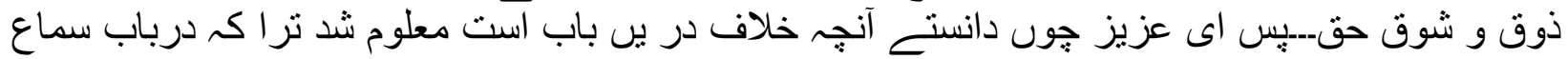

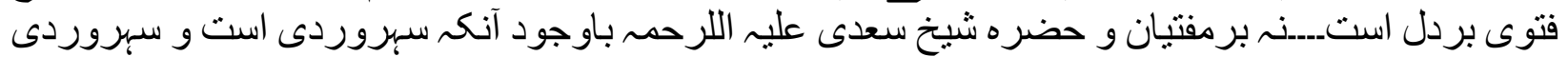
اكر مستمع را بدانم كم كيست36

منكر سماع است._-ميكويد سماع اعـ بر ادر بكويم كى جيست

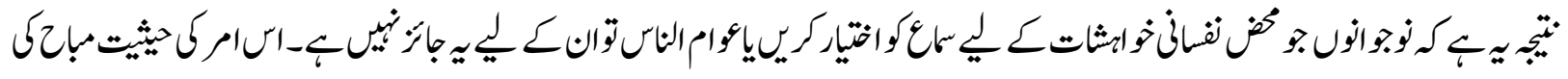

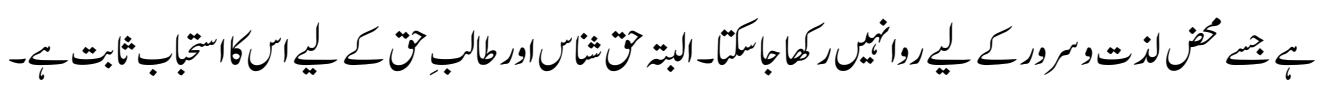

مذاهب الاولياء فى قبول الهدايا

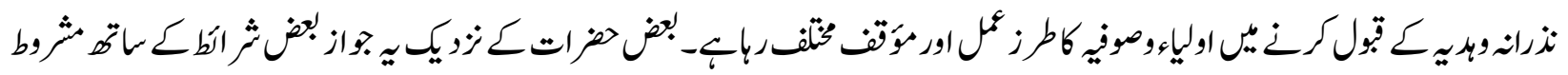

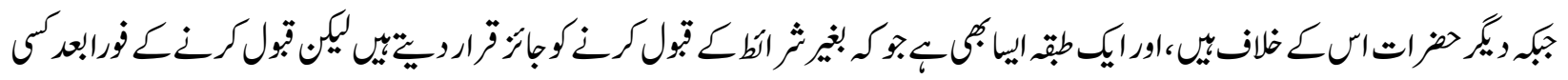

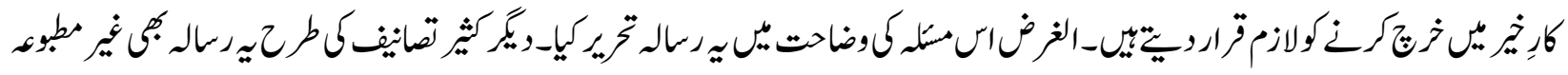

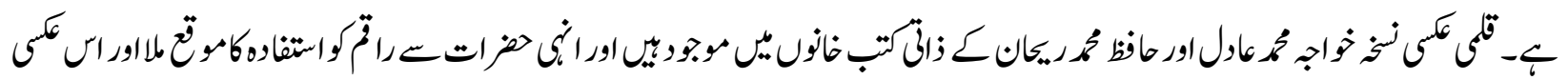

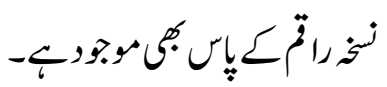

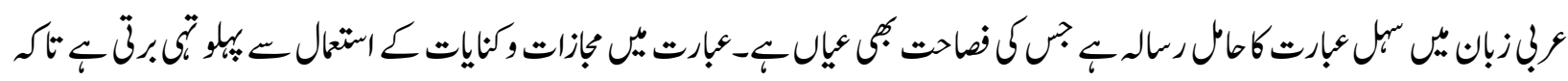

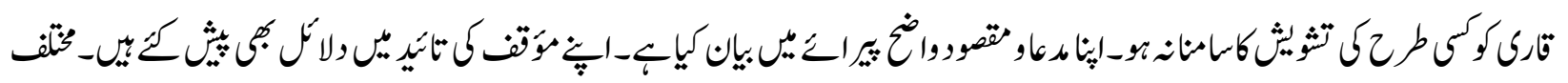

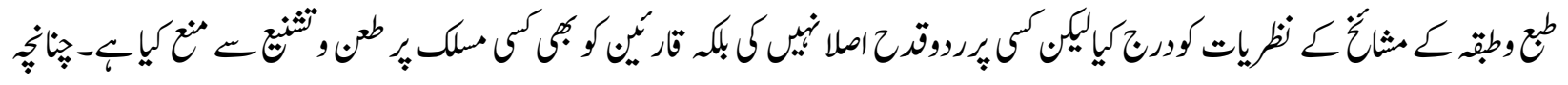

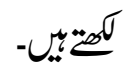

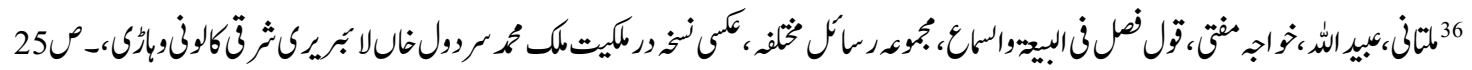




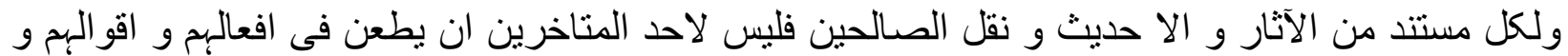

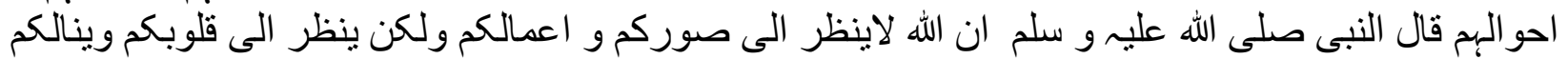

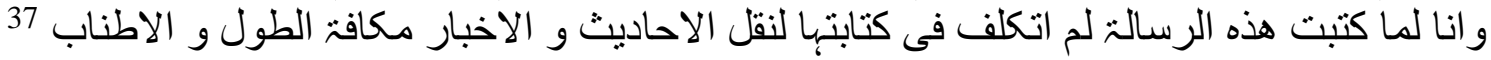

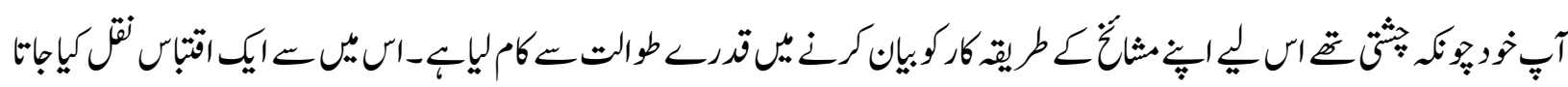

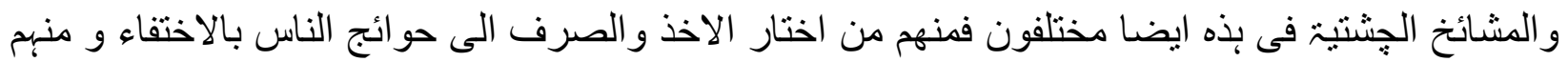

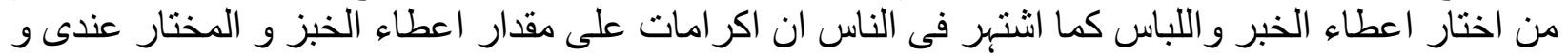

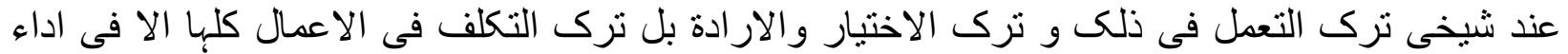

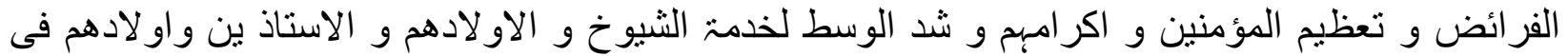

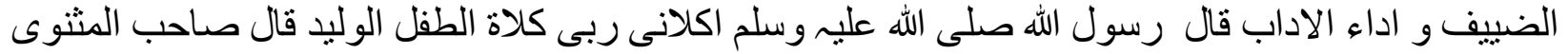

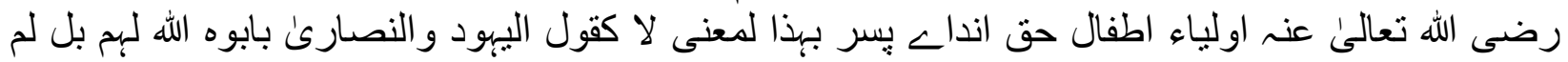

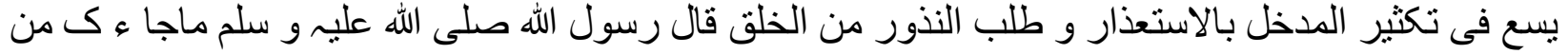

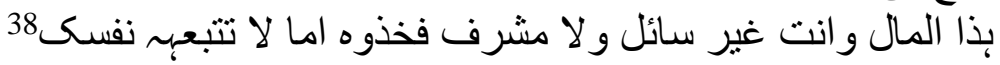

مسفار الحج

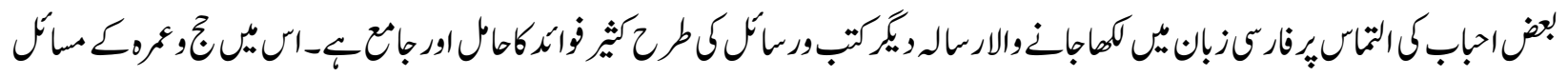

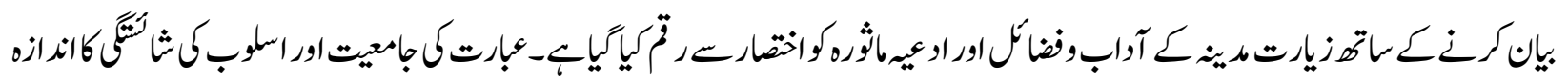

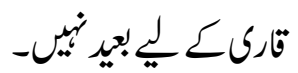

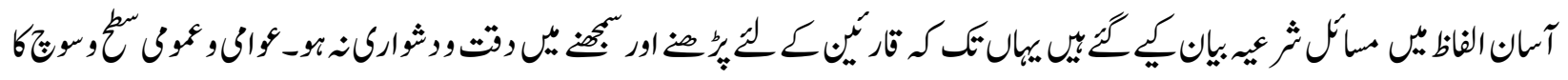

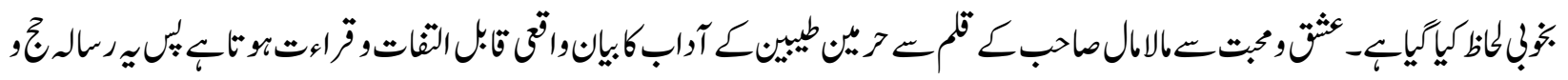

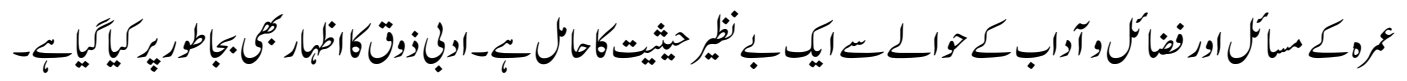

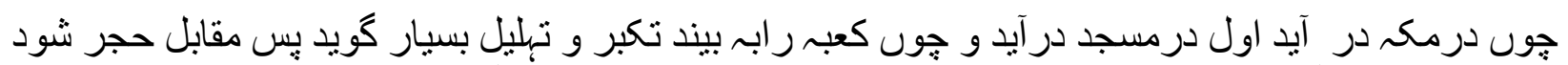

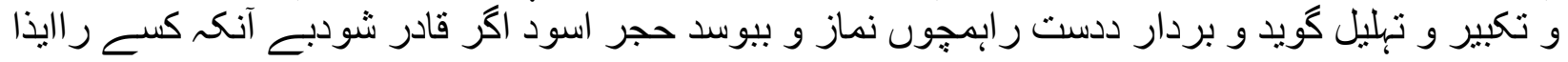

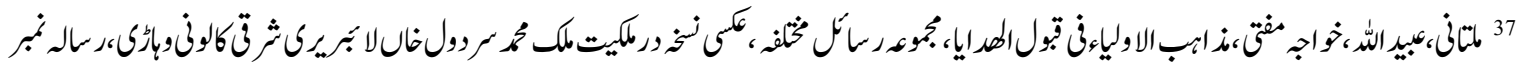
$1510 \cdot 15$

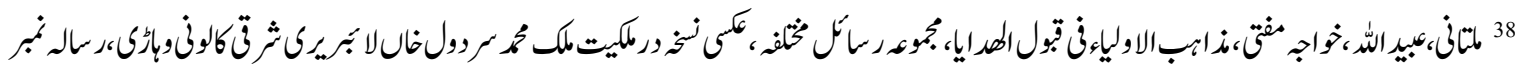
$151 \int \cdot 15$ 


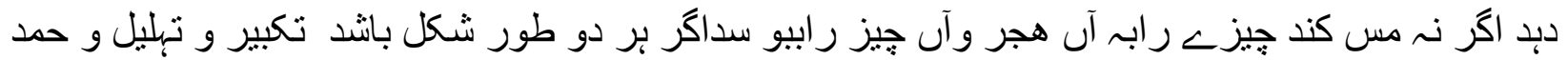

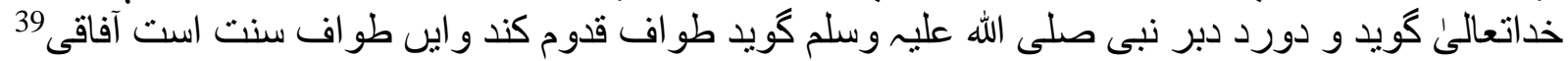

\section{ثن}

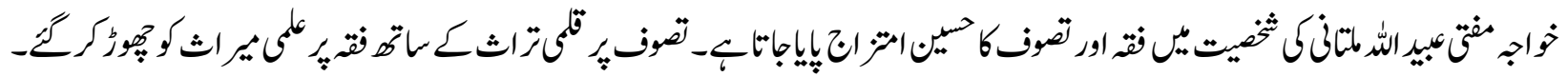

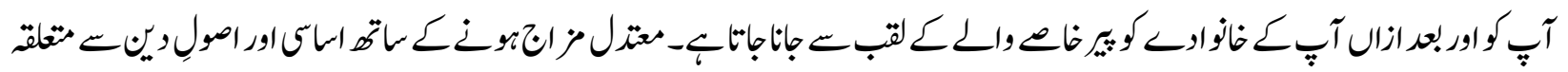

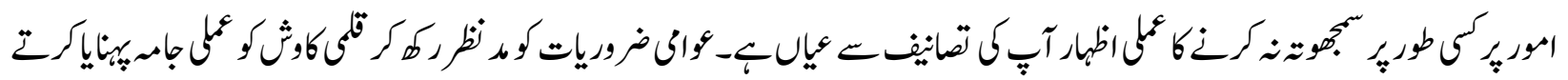

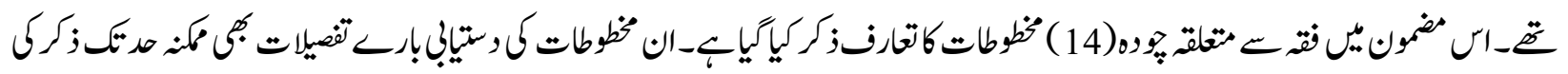

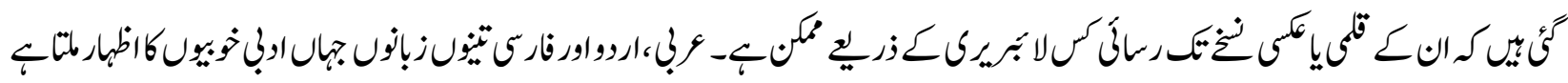

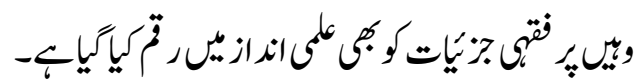

سفارثات:

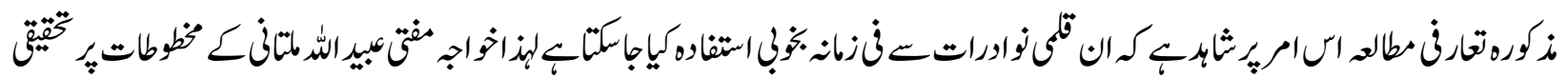

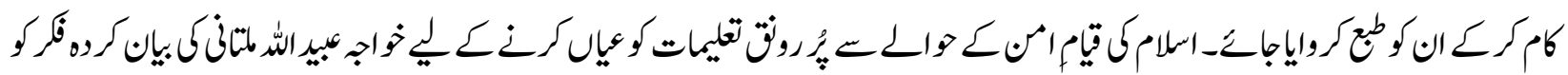

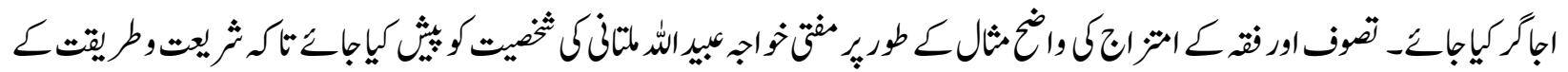

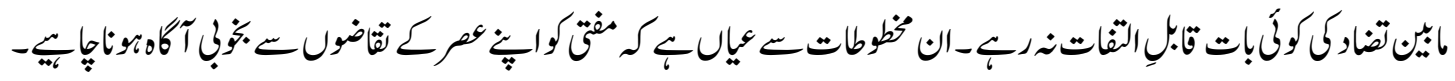

39 